\title{
RANGELAND, RARE PLANT AND WEED MONITORING IN WILLMORE WILDERNESS PARK
}

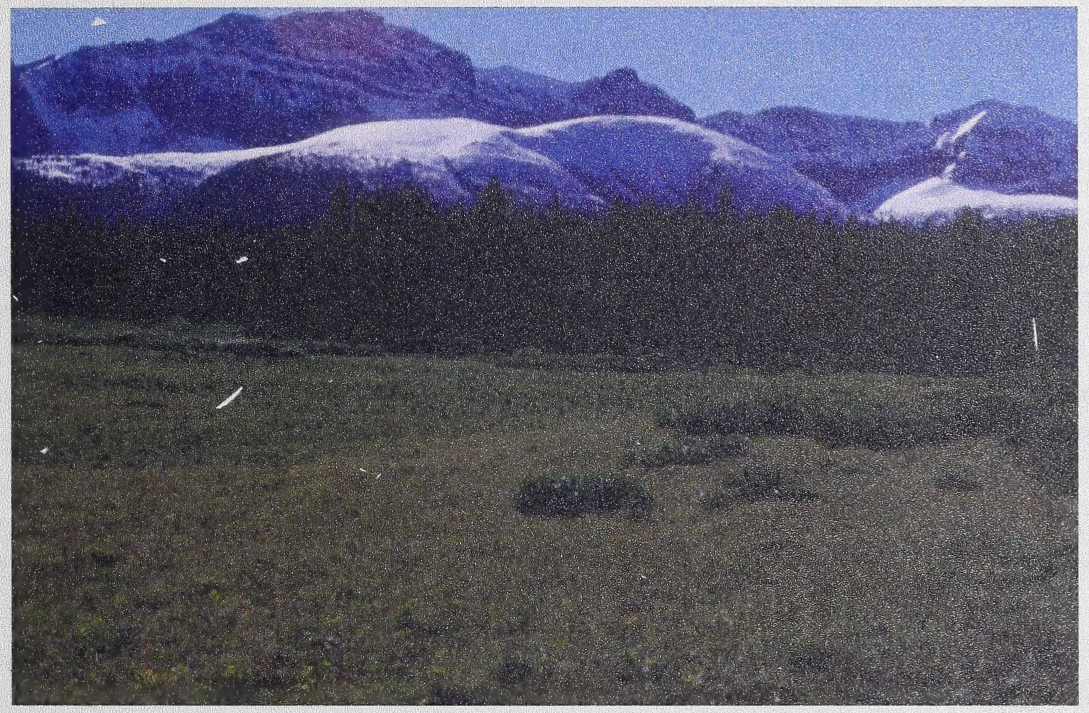

Progress Report II

for

Foothills Model Forest

September, 2000

Prepared by

Cameron Lane, Joyce Gould, Michael Willoughby, and Erica Lee
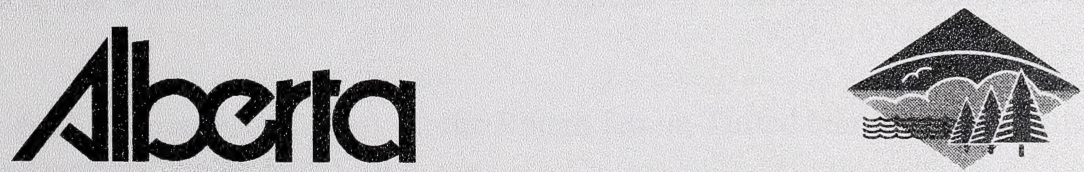

ENVIRONMENT

Land and Forest Service

Natural Resource Service 
Digitized by the Internet Archive in 2016 


\subsection{INTRODUCTION}

Willmore Wilderness Park is a 4597 square kilometre area in west-central Alberta located adjacent to the north side of Jasper National Park and east of the British Columbia border. Established in 1959, it spans a broad transition zone from boreal forest to Rocky Mountains. Being a wilderness park, and managed under such legislation, the main use of the park is for recreation. Motorised vehicle use is prohibited within the park, instead cross country skiers, hikers and back country horse users provide significant levels of traffic on the network of trails scattered throughout the park's valleys and mountain passes. The majority of use in the park each year is during the summer and fall months. The use on the rangelands comes in the form of recreational horse use, commercial guides and outfitters, offering backcountry trail riding, camping in the summer, and hunting in the fall.

The increasing level of horse use in Willmore has created concern for the condition of native ranges found throughout the park. With most of the park being heavily forested, grazing opportunities are limited to the valley bottoms and moist, semi-open drainages. Trails throughout the park generally follow the more accessible valley bottoms. Traditional camping sites located along many trails are receiving heavier intensities of grazing pressure than they can presently sustain. As a result, change to the species composition and the productivity of these native ranges is occurring in some areas. The invasion of non-native species on heavily used areas and the retention of adequate supplies of winter forage for wildlife are also areas of concern.

Recently, there has also been concern with the rate the native grasslands have been encroached by shrubs. This is a serious problem because most of the productive grasslands become inaccessible and less productive for both horses and wildlife. It is believed that the lack of fire within the Park has allowed shrubs to expand onto the remaining grassland community types.

A detailed classification of the rangeland resource in Willmore was completed by Bork (1994). It included lists of plant community types, major plant species, forage production and response to grazing pressure. At this time it was also recognised that long-term monitoring of these types was required to determine the following: range condition and trend, the effect of horse and wildlife grazing on biomass production, soils and watersheds, and to determine the successional changes on these rangelands in the presence and absence of grazing and fire disturbance. In 1998 a number of sites were established to examine the effects of shrub encroachment onto grasslands, the effect of prescribed burning on shrub and tree cover and the effect of horse and wildlife grazing on grassland vegetation. The specific objectives of the study were to:

1. Monitor shrub encroachment on an Arctic Rough fescue-Tufted hairgrass dominated community type near Eagles Nest Cabin.

2. Monitor shrub encroachment onto a Tufted hairgrass-Sedge dominated community type at Sunset creek.

3. Monitor the effect of a 1990 prescribed burn on a Bog birch-Willow/Bog sedge-Sedge dominated community type at Monaghan flats.

4. Monitor the effect of a prescribed burn on a Aspen dominated community at Kvass flats in the 
presence and absence of horse grazing.

5. Monitor the successional changes of a moderately to heavily grazed Slender wheatgrass-Sedge dominated community in the presence and absence of horse grazing at the Sulphur River cabin. 6. Monitor the effect of big horn sheep and wildlife grazing on a White Mountain avens-Sedge dominated community at Hayden ridge.

7. Assess overall range condition and determine appropriate carrying capacities (Horse Use Days) for specific range community types throughout the park.

In 1999, a number of new objectives were also added to the study. Specifically, these included:

1. An examination of forage production and species composition in the adjacent unburned aspen forest at Kvass Flats.

2. A re-examination of the original vegetation transects at the Monoghan Flats burn site.

3. An evaluation of rare plant occurrences in selected areas of Willmore.

4. An inventory of noxious weed infestations, particularly, infestation size and location.

\subsection{PHYSICAL CONDITIONS OF WILLMORE WILDERNESS PARK}

Willmore covers both foothill and mountain landforms and receives both boreal and cordilleran climate influences with significant variations in temperature, elevation, slope and precipitation (Strong 1992). The result is a wide array of plant communities in transition across the span of the park. The higher elevations of the park are represented by the Alpine and Subalpine subregions, with only limited corridors along the lower elevation river valleys indicative of the Upper Foothills subregion (Strong and Thompson 1995).

\subsection{Alpine subregion}

The alpine environment generally occurs above timberline. Ogilvie (1969), found timberline to be controlled by low temperature, wind dessication, avalanching and snow depth. The alpine plants and communities show adaptations to these extreme environmental conditions. The alpine plant communities tend to be low growing where they are protected from the wind and benefit from the warmer temperatures close to the ground (Ogilvie 1969). On south facing, wind swept ridges the bog sedge and white dryad communities are found. At slightly lower elevations where snow accumulates the low growing willow communities predominate (arctic willow, snow willow, rock willow). On the north facing slopes where snow accumulates the blackening sedge and heather community types are found. In the valley bottoms below timberline the willow, bog birch, and grassy meadow community types are typical. The sequence of plant communities in the Alpine and upper Subalpine is outlined in Willoughby and Smith (1998).

\subsection{Subalpine subregion}

The subalpine subregion is a Rocky Mountain altitudinal vegetation zone with its upper boundary formed by the Alpine subregion, whereas the lower boundary abuts the Montane, 
Foothills parkland and the Upper Foothills subregions. In Alberta, the subalpine extends from $1525 \mathrm{~m}$ to $2175 \mathrm{~m}$ at its southernmost occurrence and from $1360 \mathrm{~m}$ to $2000 \mathrm{~m}$ in the vicinity of Grande Cache (Strong 1992). The subalpine has a cordilleran climate characterised by snowy, cold winters and showery cool summers. Annual precipitation ranges from $329 \mathrm{~mm}$ to $916 \mathrm{~mm}$, with maximum precipitation falling during July. The subalpine receives more precipitation during the winter months than any subregion (Strong 1992). The mean summer temperatures average $9.4{ }^{\circ} \mathrm{C}$ and winter temperatures typically average $-8.9^{\circ} \mathrm{C}$ with December and January being the coldest months. The cold winter temperatures help to maintain the snowpack, which makes this an important watershed area.

The majority of the vegetation is dominated by seral lodgepole pine forests at lower elevations with Engelmann spruce and subalpine fir forests being more common at higher elevations. At timberline dwarf spruce, subalpine and whitebark pine are typical of the transition to the Alpine subregion. Imperfectly drained bottomlands are dominated by willow, bog birch, sedge, tufted hairgrass and california oatgrass species and the steep south facing slopes are often dominated by fescue, hairy wildrye, wheatgrass and junegrass species (Willoughby and Smith 1998).

\subsection{Upper Foothills subregion}

This subregion is found in transition below the subalpine and above the Lower Foothills subregions. It ranges in elevation from $1200-1500 \mathrm{~m}$ at lower latitudes and from $1000-1250 \mathrm{~m}$ at higher latitudes. It is dominated by closed canopy lodgepole pine forests with the potential climax species on reference sites being white spruce and black spruce. This subregion can be distinguished from the Subalpine subregion by the lack of engelmann spruce and from the Lower Foothills by the lack of aspen.

This subregion has a boreal climate, which is modified by the Rocky Mountains. The average annual precipitation is $538 \mathrm{~mm}$ with over half the precipitation received in the summer months $(340 \mathrm{~mm})$. The temperature averages $11.5^{\circ} \mathrm{C}$ in the summer and $-6.0^{\circ} \mathrm{C}$ in the winter. These temperatures are milder and not nearly as extreme as the other subregions within the Boreal forest and Foothills natural regions.

The native grass and shrubland community types are found in the valley bottoms adjacent to streams and rivers throughout the Upper Foothills subregion. Deep snow accumulations and/or cold air drainage prevent trees from growing in these valley bottoms (Daubenmire 1978). These grass and shrublands, historically burned frequently further preventing tree encroachment. The sequence of grass and shrubland community types in the Upper Foothills is outlined in Willoughby and Smith (1997).

\subsection{Rangeland monitoring}

\subsection{METHODS}

The transects established in Willmore will become part of the Alberta Environment's permanent rangeland reference area program. The Rangeland Reference Area program administered by the Land and Forest Service was established by the Eastern Rockies Forest Conservation Board to assess range condition and monitor trend on rangelands within the 
boundaries of the Rocky Mountain Forest Reserve (RMFR). To date fifty-nine reference areas have been established throughout the foothills of Alberta extending from south of Blairmore to Willmore Park. These areas include permanently marked grazed and ungrazed transects. Species composition data has been recorded on these transects since 1953 when many of the sites were established. Recently, the data of many of these sites has been analyzed in order to determine the successional pathways in the presence and absence of grazing. This long-term data used in conjunction with a detailed ecological classification of the range community types will help to determine the health of the forested rangelands in the province.

Reference sites were established on areas that represented primary range. Originally sites thought to be in poor range condition were selected. These sites were usually represented by open grasslands on south-facing slopes, benchlands and terraces. The reference sites were not located near salt or within $100-\mathrm{ft}$. $(30-\mathrm{m})$ of a fence. The preferred distance from a water source was greater than $1000-\mathrm{ft}$. (300-m) but less than 1-mi. (1.6-km).

The majority of the reference sites consist of a fenced exclosure and a 100-ft (33-m) transect inside and outside the exclosure. The outside transect was situated $25-\mathrm{ft}(8-\mathrm{m})$ or greater from the edge of the exclosure. A number of reference areas consist only of permanently marked transects. At 3-in. (7-cm) intervals, the basal frequency of the plant species was recorded using Parker's loop (Parker 1954). In 1982, the canopy cover of the plant species was also recorded (at 6-ft. (1.8-m) intervals) using a 20x50 cm Daubenmire frame. Presently, the transects are being recorded every three years. All the basal frequency data prior to 1980 was converted to canopy cover using regression analysis. In Willmore all transects are $30 \mathrm{~m}$ long and each transect will be read every $2 \mathrm{~m}$. Forbs, grass, moss and lichen canopy cover will be recorded in a 20x50 cm quadrat and canopy cover of shrubs will be recorded in a $1 \mathrm{~m}^{2}$ quadrat. At each transect one to five $50 \times 100 \mathrm{~cm}$ quadrats were clipped, separated into trees, shrubs, forbs and graminoids, oven dried and weighed. The recommended stocking rate is based on $50 \%$ of the total production and the fact one horse unit requires $682 \mathrm{~kg}$ of dry weight material for one month of grazing.

A combination of both ordination (DECORANA) (Gauch 1982) and cluster analysis (SAS) will be used to group the inside and outside transects of different years. These techniques combine the sites based on the similarity of species composition. The groupings from cluster analysis are overlain on the site ordination.

\subsection{Rare plant monitoring}

Reconnaissance surveys for rare plants were conducted for Willmore Wilderness Park and adjoining northern Jasper National Park August 4-6 and 24, 1999. Sites were accessed by helicopter with approximately 2-4 hours spent at each site and attempts were made to visit sites of various lithologies. The focus of the survey was on alpine areas since these are most easily accessed by helicopter. Surveys of more accessible areas can be done at a later date. Attempts were made to visit selected areas where rare plants had been noted previously (as determined by a search of the Alberta Natural Heritage Information Centre (ANHIC) databases) however, most of the effort was directed toward areas that had not been surveyed in the past. As many habitats 
as possible were surveyed for rare plants during each stop and a verbal description of habitat and population size was taken for each rare plant noted. Rare plants are those listed on the Alberta Natural Heritage Information Centre Plant Species of Special Concern, February 1999 (Gould 1999). Locations of rare species were noted with the Garmin 45 hand held GPS unit and photographs of rare plants and/or their habitats were taken where possible. Voucher specimens were collected for many taxa to confirm identification against annotated material at the University of Alberta herbarium and/or to document a new occurrence for Willmore Wilderness Park or Jasper National Park. These specimens will be deposited in the University of Alberta herbarium.

Joyce Gould conducted the surveys on August 4-6 and 24 and Dr. Peter Achuff, Jasper National Park assisted on August 6 and 24. Dr. René Belland, Devonian Botanic Garden, University of Alberta joined the party on August 24 to search for rare bryophytes.

All occurrences of rare plants were entered into the ANHIC databases. The tracking lists for rare species were updated in November and December 1999 and species that had been noted for Willmore Wilderness Park and/or Jasper National Park that are now included on this list were included in this report.

\subsection{Noxious weeds}

The Weed Management Program for Land and Forest Service seeks to alleviate the effects of non-native plants by: 1 . Conducting inventories and identifying areas with infestations 2. Controlling known infestations by a variety of means including, hand picking, mowing, applying herbicides and rehabilitation of disturbed areas and 3. Monitoring to see if controls are effective. In the North East Slopes region of Land and Forest Service a number of weeds have been identified as a concern. These include diffuse knapweed, spotted knapweed, nodding thistle, yellow starthistle, scentless chamomile, tansy, yellow toadflax, oxeye daisy, tall buttercup and Canada thistle. In adjacent Jasper National Park leafy spurge, purple loosestrife, dalmation toadflax, bladder campion and field bindweed have also been listed as a concern for control. In 1998 and 1999 a weed inspector was assigned to the rangeland monitoring program in an effort to identify locations and size of weed infestations in Willmore Wilderness Park.

\subsection{Rangeland Monitoring}

\subsection{RESULTS}

Willoughby $(1997,1998)$ has found that it takes 20-30 years of continuous monitoring before species composition changes can be detected from reduced grazing pressure or as a result of shrub encroachment. It is likely that it will take longer to detect species composition changes in the grass and shrublands of Willmore because of the harsh growing conditions found in the mountainous terrain. The results outlined here will discuss the general ecology, objectives and expected results for each site established in Willmore in 1998. 


\subsubsection{Eagles Nest Cabin transect}

This transect was established in a Arctic Rough fescue-Tufted Hairgrass dominated community just south of Eagles Nest cabin (Appendix A) to examine the effect of shrub encroachment onto the native grasslands. This community type is transitional between the Subalpine and Upper Foothills subregions. It represents the transition zone from the dry Junegrass/Sage dominated slopes to the moist tufted hairgrass, sedge dominated community types (Willoughby and Smith 1997). These grasslands are fairly moist and have well developed soils which makes them very productive. Morgantini and Russell (1983), found that rough fescue dominated community types were the primary foraging areas for elk in the Ya Ha Tinda area. The presence of rough fescue likely makes this community type important for wildlife in Willmore.

Succession in the absence of disturbance is to a Bog birch/Rough fescue dominated community(Willoughby and Smith 1997). The Bog birch community type generally has a half to a third less forage than the rough fescue dominated community types.

\subsubsection{Sunset Creek transect}

This transect was established in a Tufted hairgrass-Sedge dominated community type at the confluence of the Sunset creek and the North Berland river (Appendix A) in order to examine the effect of shrub encroachment onto the native grasslands. This community type is typical of moist meadows in both the Subalpine and Upper Foothills subregions (Willoughby and Smith 1997). This community type is drier than the pure sedge meadows, but moister than the rough fescue dominated community types.

Willoughby (1998) found that when this community is protected from grazing or fire for 25-30 years, willow and bog birch expanded and tufted hairgrass and sedge decline in the Upper Foothills subregion. The decline in graminoid cover also results in a decline in available forage production (2200 to $1800 \mathrm{~kg} / \mathrm{ha})$.

\subsubsection{Monaghan burn transect}

This transect was established at Monaghan flats (Appendix A) in order to examine the effect of the 1990 prescribed burn on the Bog birch-Willow/Bog sedge dominated community. The purpose of the original burn was to reduce willow and bog birch cover in an effort to increase forage supply (MacCallum and Yakimchuk 1992). The original vegetation transects were relocated in 1999. An evaluation of the vegetation data from 1990,1991 and 1999 is reported in Appendix B.

\subsubsection{Kvass burn exclosure}

This exclosure was established in a burned aspen stand adjacent to Kvass flats (Appendix A) in order to examine the effects of fire and horse grazing on aspen regeneration and forage production. In 1999, an examination of forage production and species composition in the adjacent unburned aspen forest was made. The report outlined in Appendix $\mathrm{C}$ discusses the differences in forage production, species composition and species diversity between the 
unburned aspen forest and the adjacent burned area.

\subsubsection{Sulphur exclosure}

This exclosure was established in a Slender wheatgrass-Sedge dominated community type, near the Sulphur River cabin (Appendix A). The site has been extensively utilized by horses. Bork (1994) felt that this community type represented heavily grazed tufted hairgrass or rough fescue dominated community types. It was felt that heavy grazing pressure caused fescue or hairgrass to decline in the stand and allowed sedge and slender wheatgrass to increase. By establishing an exclosure at this site the successional pathways of this community type in the presence and absence of grazing can be determined. An understanding of the successional pathways will allow range condition of this site and similar community types within Willmore to be determined.

\subsubsection{Hayden ridge exclosure}

This wildlife exclosure was established by a M.Sc. student in a White mountain avens dominated community in the mid 1970's (Appendix A) These white mountain aven communities are extensively utilised by bighorn sheep during the winter months because they remain snow free. Transect readings from both inside and outside the exclosure indicate only slight differences between the grazed and ungrazed transects (Table 1). The outside transect has a larger number of species which one would expect in a grazed situation (Willoughby 1995). The inside transect has a lower number of species and evidence of low growing woody species (willow, bilberry) which are not found on the outside transect. The increase in woody species inside the exclosure maybe the result of increased moisture and not the result of being ungrazed by wildlife. Exclosures in Southern Alberta tend to be moister in the absence of grazing because the increased litter inside the exclosure tends to catch more snow. Efforts are currently being made to locate the original data from this study. 
Table 1. Species canopy cover inside and outside the Hayden ridge exclosure in Willmore Wilderness Park in 1998.

$\begin{array}{lll}\text { Species } & \text { In }\end{array}$

\section{Grasses}

Bog sedge

Hairy wildrye

Arctic rough fescue

\section{Forbs}

White mountain avens

Alpine hedysarum

Alpine bistort

White camas

Shrubs

Dwarf bilberry

Rock willow

\section{Lichens}

Reindeer lichen

Dog lichen

Species richness
6

6

$\mathrm{T}$

9

$\mathrm{T}$
T

$39 \quad 42$

2 T

43

11

$\mathrm{T}$

$\mathrm{T}$

40

10

- 2

19

\subsection{Rare plant monitoring}

Thirty-nine species of rare vascular plant had been reported for Willmore Wilderness Park and adjoining northern Jasper National Park prior to this survey (ANHIC data files). Two of these records are from Jackpine Pass and are historical (1924) and it is not known whether they were collected from Willmore or Jasper.

Twenty-four rare vasculars and one rare moss were reported during the course of this study. Included in this are seven new taxa for the area. This brings the total number of rare vascular plant species for the area to forty-six (Table 2). The new taxa are Artemisia furcata var. furcata, Cardamine bellidifolia, Carex incurviformis var. incurviformis, Erigeron trifidus, Huperzia halaekalae, Salix alaxensis and Silene involucrata var. involucrata. In addition to the rare vasculars, one rare moss was found--Stegonia pilifera. 
Table 2. Rare vascular plants from Willmore Wilderness Park and northern Jasper National Park

\begin{tabular}{|c|c|}
\hline Scientific Name & Common Name \\
\hline Antennaria corymbosa" & corymbose everlasting \\
\hline Antennaria monocephala* "“ & one-headed everlasting \\
\hline Anthoxanthum monticola* "“ & alpine sweet grass \\
\hline Aquilegia formosa" & Sitka columbine \\
\hline Aquilegia jonesii“" & Jones' columbine \\
\hline Arabis lemmonii* “ & Lemmon's rock cress \\
\hline Artemisia furcata var. furcata* & forked wormwood \\
\hline Botrychium minganense" & Moonwort \\
\hline Braya purpurascens* "“ & alpine braya \\
\hline Cardamine bellidifolia* & alpine bitter cress \\
\hline Cardamine umbellata“" & mountain cress \\
\hline Carex heleonastes" & Hudson Bay sedge \\
\hline Carex incurviformis var. incurviformis* & seaside sedge \\
\hline Carex petricosa" & stone sedge \\
\hline Cryptogramma stelleri “" & Steller's rock brake \\
\hline Draba longipes" & whitlow-grass \\
\hline Draba macounii" " & Macoun's whitlow-grass \\
\hline Epilobium lactiflorum" & Willowherb \\
\hline Erigeron flagellaris “ & creeping fleabane \\
\hline Erigeron trifidus* & trifid-leaved fleabane \\
\hline Eriophorum callitrix" & beautiful cotton grass \\
\hline Festuca altaica*“" & northern rough fescue \\
\hline Gentiana glauca*“ & alpine gentian \\
\hline \multicolumn{2}{|l|}{ Huperzia haleakalae* } \\
\hline Loiseleuria procumbens " & alpine azalea \\
\hline Minuartia elegans*" & purple alpine sandwort \\
\hline Osmorhiza purpurea" & purple sweet cicely \\
\hline Papaver kluanesis*" & alpine poppy \\
\hline Pedicularis capitata*"“ & large-flowered lousewort \\
\hline Pedicularis flammea* " & flame-coloured lousewort \\
\hline Pedicularis lanata* " & woolly lousewort \\
\hline Pedicularis langsdorfii ssp. arctica " & Arctic lousewort \\
\hline Pyrola grandiflora* “" & Arctic wintergreen \\
\hline Ranunculus nivalis *“ & snow buttercup \\
\hline Ranunculus occidentalis var. brevistylis" & western buttercup \\
\hline Ribes laxiflorum" & mountain currant \\
\hline Salix alaxensis* & Alaska willow \\
\hline Salix commutata" & changeable willow \\
\hline Saxifraga ferruginea $*$ " & saxifrage \\
\hline Saxifraga flagellaris ssp. setigera* “ & spiderplant \\
\hline
\end{tabular}




\begin{tabular}{|l|l|}
\hline Saxifraga nelsoniana ssp. porsildiana* “ & Nelson's saxifrage \\
\hline Saxifraga nivalis* “ & alpine saxifrage \\
\hline Silene involucrata var. involucrata* & alpine bladder catchfly \\
\hline Thuja plicata “ & western red cedar \\
\hline Vaccinium ovalifolium “ & oval-leaved blueberry \\
\hline Vaccinium uliginosum “ & bog bilberry \\
\hline
\end{tabular}

* noted in the course of this study

" previously reported for area (from ANHIC data files, Oct. 1999)

Most of the rare plants noted during this survey were from the alpine due in part to the disproportionate amount of time spent in the alpine compared with the subalpine and valley bottoms. Only one rare plant, northern rough fescue (Festuca altaica) was noted from the valley bottoms. Additional surveys of the valley bottoms should be done.

In addition to the plants noted above, two Viola's were collected from northern Jasper National Park. Specimens of these two taxa were reviewed by Dr. John Packer, professor emeritus, University of Alberta, and are of considerable interest as one may represent a new addition to the Alberta flora. The specimens will be sent to an expert for review and proper determination.

A more detailed description of the rare plant work done as part of this study is provided in Appendix D.

\subsection{Noxious weeds}

Noxious weed infestations have been isolated to tall buttercup (Ranunculus acris ) mainly surrounding campsites, clearings and other heavily used recreation areas. In total 19 occurrences, from light to heavy infestations, have been tracked based on weed inventories in 1998 and 1999 (Appendix E). It is generally understood that the source of tall buttercup has been introduced from hay brought into the park as feed on horse trips. Tall buttercup has established on these heavily used recreation areas and has increased into larger infestations with overgrazing and traffick. Tall buttercup is toxic to livestock and thereby increases with localized overgrazing.

\subsection{DISCUSSION AND MANAGEMENT IMPLICATIONS}

\subsection{Rangeland monitoring}

Monitoring these rangeland sites in Willmore will establish a benchmark to determine the ecological climax and successional changes of these range communities. It will provide an assessment of range condition of similar range types altered by domestic or wildlife grazing, flooding, or lack of natural wild fire. Understanding succession and the ecological diversity of these range types will assist in developing management schemes throughout the park.

In addition to monitoring species diversity, biomass production was also collected to 
determine the amount of forage available for domestic and wildlife grazing. Based on current biomass production $(\mathrm{kg} / \mathrm{ha}$ ) carrying capacities of each site were assessed based on $50 \%$ allocation of total production and 1.5 Animal Units for a horse. This establishes a stocking rate (Horse Days per hectare) to enable land managers to allocate appropriate amount of horse use levels that sustain the natural range types within a given area (Table 2).

However, it must be understood that to ensure the continued productivity and survival of some native range types, particularly those that have been overgrazed, much lower stocking rates are needed for range recovery to occur. Domestic grazing can also be used, in conjunction with prescribed fire, to restrict shrub and tree encroachment thereby protecting these natural range types.

Monitoring species composition and biomass production establishes an ecological evaluation of how these range types are changing overtime based on current management practices. It provides information on the condition of the park and provides guidelines on how to manage these range types to maximize species richness, diversity, productivity, wildlife habitat, and aesthetics.

Table 3. Biomass production and stocking rates for sites monitored in Willmore Wilderness Park, 1998, 1999.

\begin{tabular}{cccc} 
Site Description & Range Community Types & $\begin{array}{c}\text { Biomass } \\
\text { Production } \\
\text { (kg/ha) }\end{array}$ & $\begin{array}{c}\text { Stocking Rate } \\
\text { (H.D./ha) }\end{array}$ \\
\hline Kvass Flats & Aspen-Rose/Hairy Wild Rye & 1645 & 37 \\
Sulphur-Kvass & Slender Wheatgrass - Sedge & 693 & 15 \\
Monoghan Flats & Bog birch-Willow/Bog Sedge & 2022 & 45 \\
Hayden Ridge & White Mountain Avens & 289 & Non-use \\
Sunset Creek & Tufted Hairgrass-Sedge & 2264 & 50 \\
Eaglesnest & Arctic Rough Fescue-Tufted & 1374 & 30 \\
\hline
\end{tabular}

\subsection{Rare plant monitoring}

Several rare plants are known in Alberta only from Willmore and/or adjacent northern Jasper National Park. However, large portions of these two areas have never been surveyed for rare taxa particularly for rare bryophytes.

Rare species are important components of the ecosystem and are often used as indicators for various monitoring programs related to the conservation of biodiversity. Collection of 
baseline information on rare species, such as population size and habitats, is the first step in the implementation of any monitoring program. This study was an attempt to document such baseline information for a portion of the area.

This survey has resulted in the discovery of several new rare taxa for either Willmore and/or Jasper National Parks. Additional surveys in previously unexplored areas will be of great value in determining the distribution and population sizes of these, and other rare taxa, within Willmore and northern Jasper National Parks. Ultimately, this information can be used to determine the significance of these taxa in a provincial context.

Documentation of the location of these taxa, along with information on population sizes, habitats and management concerns, will form the basis for subsequent monitoring actions. Accurate documentation of location, with supplemental information on the population, can be used to revisit the sites in subsequent years.

Relocation of previously documented taxa is in large part dependent upon accurate locational information. We were able to relocate some taxa that had been reported in the past however, given the poor locational information on the original data, it is uncertain whether these represented rediscovery of the original sites or new locations. Further attempts at mapping populations of rare plants within the entire area of interest will help to ascertain distribution and status within such. Such information can then be used as a foundation for management planning and a rare plant monitoring program.

\subsection{Noxious weeds}

Weeds are typically non-native plants that threaten the ecological integrity of native ecosystems. Many of the worst offenders come from as far away as Europe and Asia. Locally these introduced species have no natural predators or parasites to control their spread. As a result, they tend to crowd out the local vegetation and in severe cases, produce single plant communities. This decreases the diversity and cover of native vegetation, which also reduces the grazing potential of the area. Most non-native species are less palatable and may cause discomfort or death of the animal if eaten.

Without control, non-native plants can spread rapidly. Seeds are small and move easily with equipment and as impurities in seed and feed. Under the Weed Control Act of Alberta weeds designated as noxious must be controlled. Controlling infestation when small is the best option besides prevention. Appropriate action reduces economic, environmental, aesthetic and ecological impacts of undesired plants. Currently, Land and Forest Service is working with various stakeholder groups to raise awareness, prevention, and implement practical measures to control the spread of tall buttercup. 


\subsection{LITERATURE CITED}

Bork, E. 1994. Ecological classification and management of native range in Willmore Wilderness Park. Alberta Environmental Protection. Forest Management Division. Edmonton, AB. Pub. no. T/282. 65pp.

Bork, E, D. Smith and M.G. Willoughby. 1996. Prescribed burning of bog birch. Rangelands. 18: 4-7.

Daubenmire, R. 1978. Plant Geography. Academic Press. New York. 338 pp.

Gauch, H.G. 1982. Multivariate analysis in community ecology. Cambridge University Press. Cambridge, 298 pp.

Gould, J. 1999. Plant Species of Special Concern. Alberta Natural Heritage Information Centre, Alberta Environmental Protection, Edmonton, AB.

Ogilvie, R.T. 1969. The mountain forest and alpine zones of Alberta. In Vegetation Soils and Wildlife. Edited by J.G. Nelson and M.J. Chambers. Methuen Publications, Toronto. pp 2444.

Parker, K.W. 1954. A method for measuring trend in range condition on national forest ranges. U.S. Forest Service, Washington, D.C. 26pp.

MacCallum, B. and R. Yakimchuk. 1992. Evaluation of the effects of one prescribed burn on a Willow/Bog birch meadow in the Subalpine Ecoregion of Alberta. Rocky Mtn. Elk Foundation and Alberta Fish and Wildlife Division. 50pp.

Morgantini, L.E. and W.B. Russell. 1983. An assessment of three selected elk winter ranges in the Rocky Mountain Region. Alberta.Fish and Wildlife. Edmonton, AB. 265 pp.

Strong, W.L. 1992. Ecoregions and ecodistricts of Alberta. Vol. I. Alberta Forestry Lands and Wildlife, Land Information Services Division, Resource Information Branch, Edmonton, AB. $\mathrm{T} / 244.77 \mathrm{pp}$.

Strong, W.L. and J.M. Thompson. 1995. Ecodistricts of Alberta. Summary of Biophysical Attributes. Alberta Environmental Protection, Resource Data Division. Edmonton, AB. Pub. no. T/319. 91pp.

Willougbhy, M.G. 1995. Species diversity and how it is affected by livestock grazing on Alberta's Eastern slopes. Proceedings Fifth International Rangeland Congress. Salt Lake City, Utah. July 1995. Pg 610-611. 
Willoughby, M.G. and D. Smith. 1997. Range plant community types and carrying capacity for the Upper Foothills subregion. Dept. of Environmental Protection. Land and Forest Service. Edmonton. AB. Pub. No. T/356. 76pp.

Willoughby, M.G. and D. Smith. 1998. Range plant community types and carrying capacity for the Subalpine subregion. Dept. of Environmental Protection. Land and Forest Service. Edmonton. AB. 108pp.

Willoughby, M.G. 1997. Rangeland Reference Areas; Castle River range condition and trend from 1953-1995. Dept. of Environmental Protection. Land and Forest Service. Edmonton. AB. Pub. No. T/358. 22pp.

Willoughby, M.G. 1998. Rangeland Reference Areas; Seven mile creek range condition and trend from 1964-1997. Dept. of Environmental Protection. Land and Forest Service. Edmonton. AB. Pub. No. T/403. 20pp. 
APPENDIX A:

SITE DESCRIPTIONS AND PHOTOS 


\section{Eagle's nest cabin transect}

Region - Northeast Slopes; District - Foothills; Date established - 1998; Location Twp. 52, Rge. 4 Sec. 22 NW W6 (N 53.30.477, W118.29.946); Elevation-1614 m; Nutrients - permesotrophic; Drainage - well; Moisture - subhygric; Geological formation: Old flood plain, Glacial Fluvial parent material; Soil Classification - Orthic Regosol; Description of Area - rough fescue, hairy wildrye, tufted hairgrass meadow surrounded by willow and bog birch shrublands; Major species present, rough fescue (Festuca scabrella), tufted hairgrass (Deschampsia cespitosa), slender wheatgrass (Agropyron trachycaulum), hairy wildrye (Elymus innovatus) sedge spp (Carex spp.) Veiny meadow rue (Thalictrum venulosum), yellow beardtongue (Penstemon confertus); Seral stage - young edaphic climax; Transect locations - $30 \mathrm{~m}$ long, read every $2 \mathrm{~m}$ starting at $2 \mathrm{~m}$, read on right hand side of the tape, read from west to east; This transect was one of a number of transects established to monitor shrub encroachment onto the remaining grassland meadows within Willmore Wilderness Park.

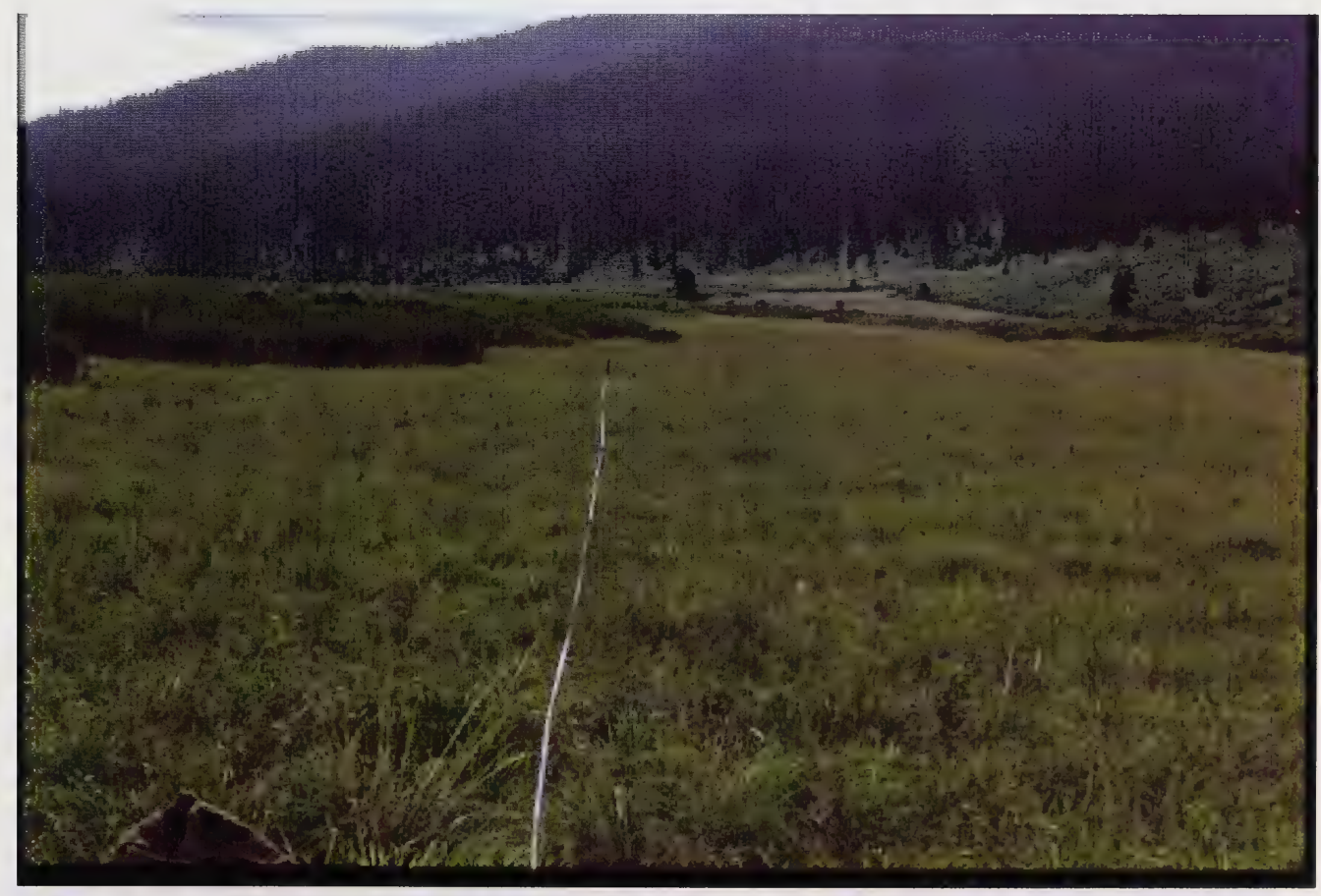





\section{$\underline{\text { Sunset transect }}$}

Region - Northeast Slopes; District - Foothills; Date established - 1998; Location Twp. 54, Rge. 5 Sec. 30 SE W6 (N 53.41.982, W 118.43.600); Elevation -1630 m; Nutrients - permesotrophic; Drainage - well; Moisture - subhygric-hygric; Parent material: Fluvial; Soil Classification: Cumulic Humic Regosol; Description of Area tufted hairgrass meadow surrounded by willow and bog birch shrublands; Major species present tall lungwort (Mertensia paniculata), monkshood (Aconitum delphinifolium), tufted hairgrass (Deschampsia cespitosa), slender wheatgrass (Agropyron trachycaulum), sedge spp (Carex spp.) Veiny meadow rue (Thalictrum venulosum); Seral stage - young edaphic climax; Transect locations - $30 \mathrm{~m}$ long, read every $2 \mathrm{~m}$ starting at $2 \mathrm{~m}$, read on right hand side of tape from north to south; This transect was one of a number of transects established to monitor shrub encroachment onto the remaining grassland meadows within Willmore Wilderness Park.

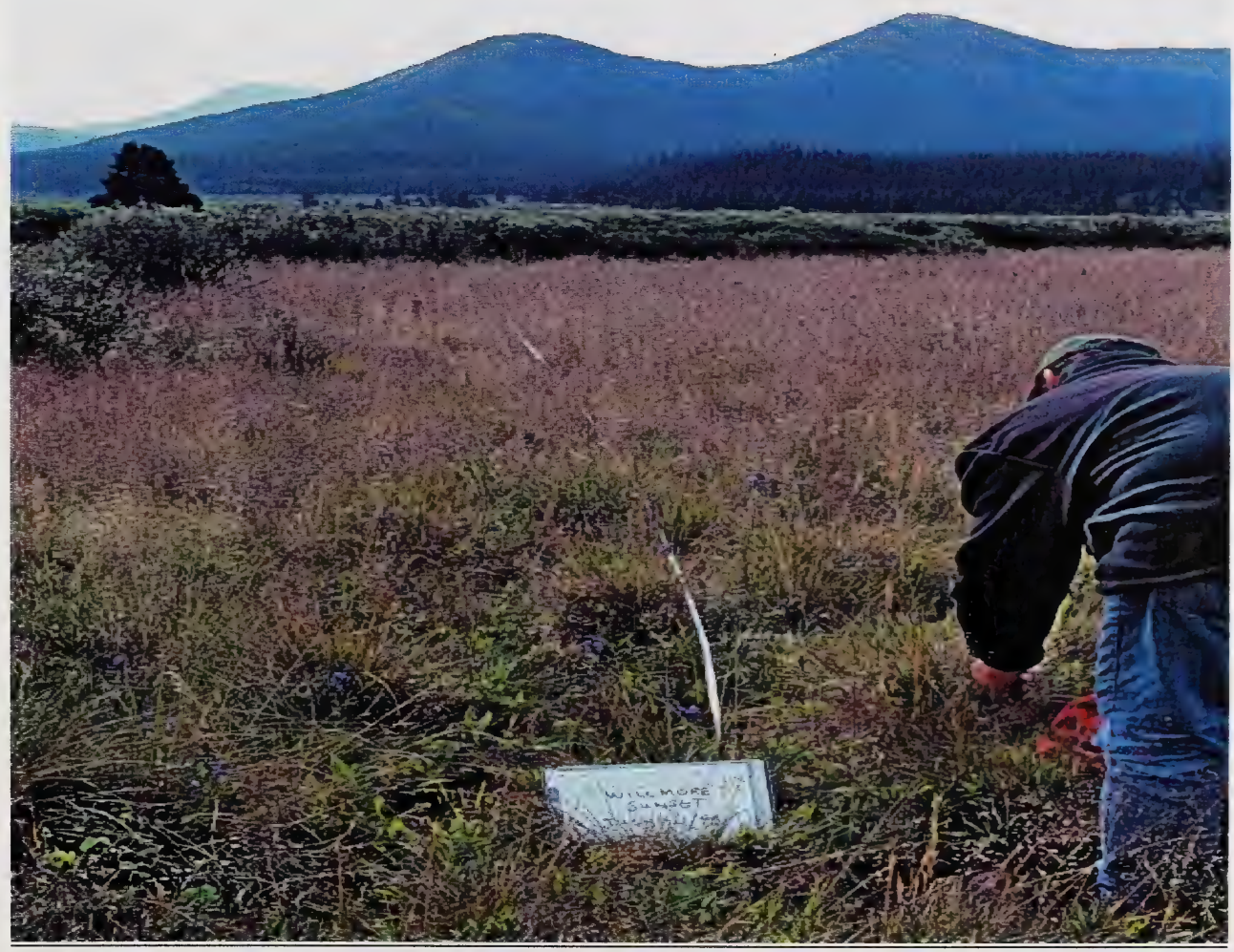





\section{Monoghan burn transect}

Region - Northeast Slopes; District - Foothills; Date established - 1998; Location Twp. 53, Rge. 7 Sec. 23 SE W6 (N 53.35.227, W118.55.172); Elevation -1530 m; Nutrients - permesotrophic; Drainage - well; Moisture - subhygric; Soil Classification Orthic Humic Regosol; Parent material-alluvial deposits on top of outwash gravels; Description of Area - Bog birch, willow shrubland which was burned in the spring of 1990; Major species present, Bog birch (Betula glandulosa), willow (Salix spp.), bog sedge (Kobresia myosuroides), slender wheatgrass (Agropyron trachycaulum), sedge spp (Carex spp.) california oatgrass (Danthonia californica), strawberry (Fragaria virginiana); Seral stage - young edaphic climax; Transect locations $-30 \mathrm{~m}$ long, read every $2 \mathrm{~m}$ starting at $2 \mathrm{~m}$, read on right hand side of tape from east to west; This transect was established to monitor the effects of the 1990 burn on bog birch and willow cover at Monoghan flats within Willmore Wilderness Park.

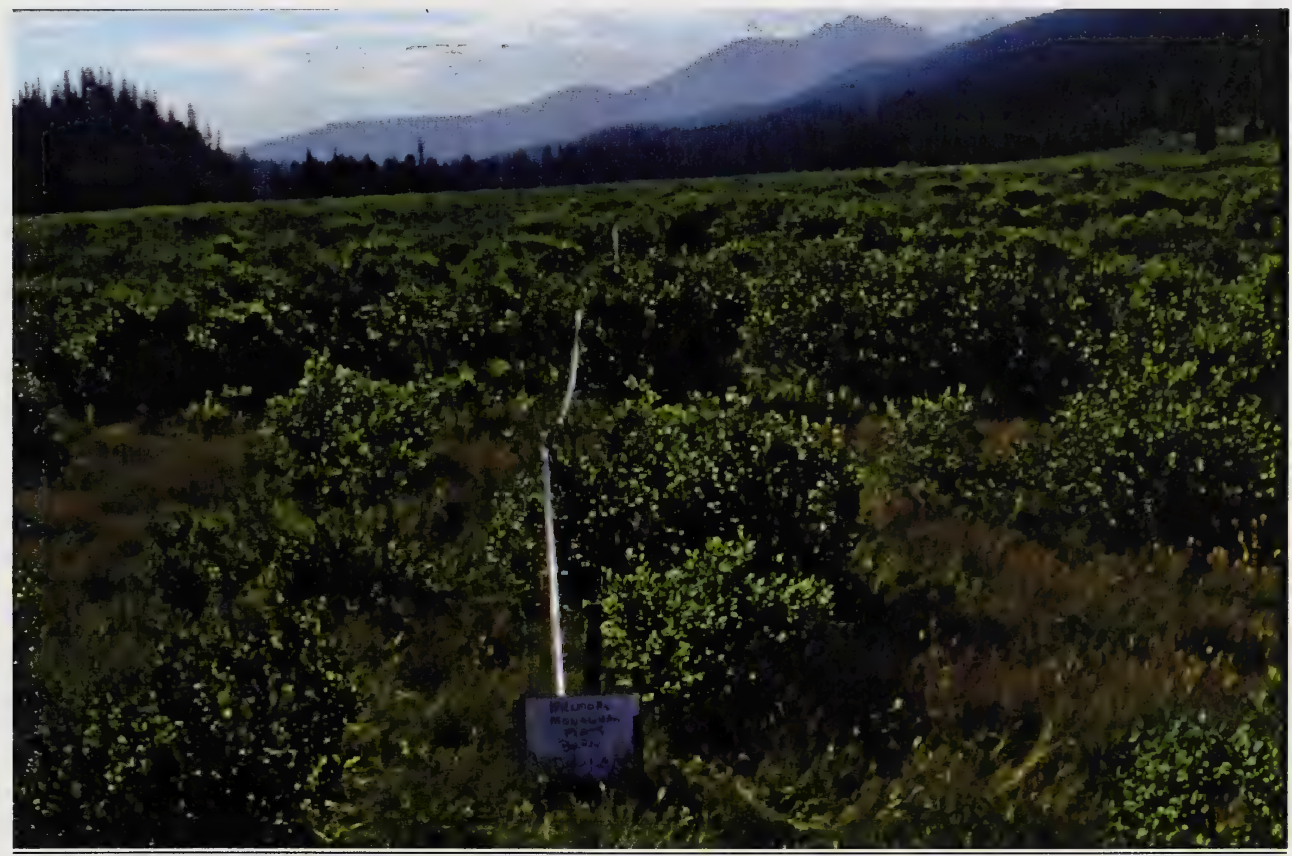





\section{$\underline{\text { Kvass burn exclosure }}$}

Region - Northeast Slopes; District - Foothills; Date established - 1998; Location Twp. 56, Rge. 9 Sec. 3 NE W6 (N 53.49.02, W119.14.850); Elevation-1060 m; Aspect - $180^{\circ}$; Slope - 20\%; Nutrients - mesotrophic; Drainage - well; Moisture - mesic; Soil Classification - Orthic Humic Regosol; Parent material - coarse textured colluvial deposits, on slopes above the Smoky River; Description of Area - aspen stands which were burned in 1996; Major species present, slender wheatgrass (Agropyron trachycaulum), sedge spp (Carex spp.) hairy wildrye (Elymus innovatus) snowberry (Symphoricarpos occidentalis), rose (Rosa acicularis), strawberry (Fragaria virginiana), Lindley's aster (Aster ciliolatus), showy aster (Aster conspicuus); Seral stage - early seral; Exclosure construction - $20 \times 30 \mathrm{~m}$ with wood and steel posts and two strands of barbed wire; Transect locations - $30 \mathrm{~m}$ long, read every $2 \mathrm{~m}$ starting at $2 \mathrm{~m}$, read on right hand side of tape from north to south, the outside transect is located $3 \mathrm{~m}$ to the east of the exclosure and is read from north to south; This exclosure was established to monitor the effects of the prescribed burn at Kvass flats in Willmore Wilderness Park

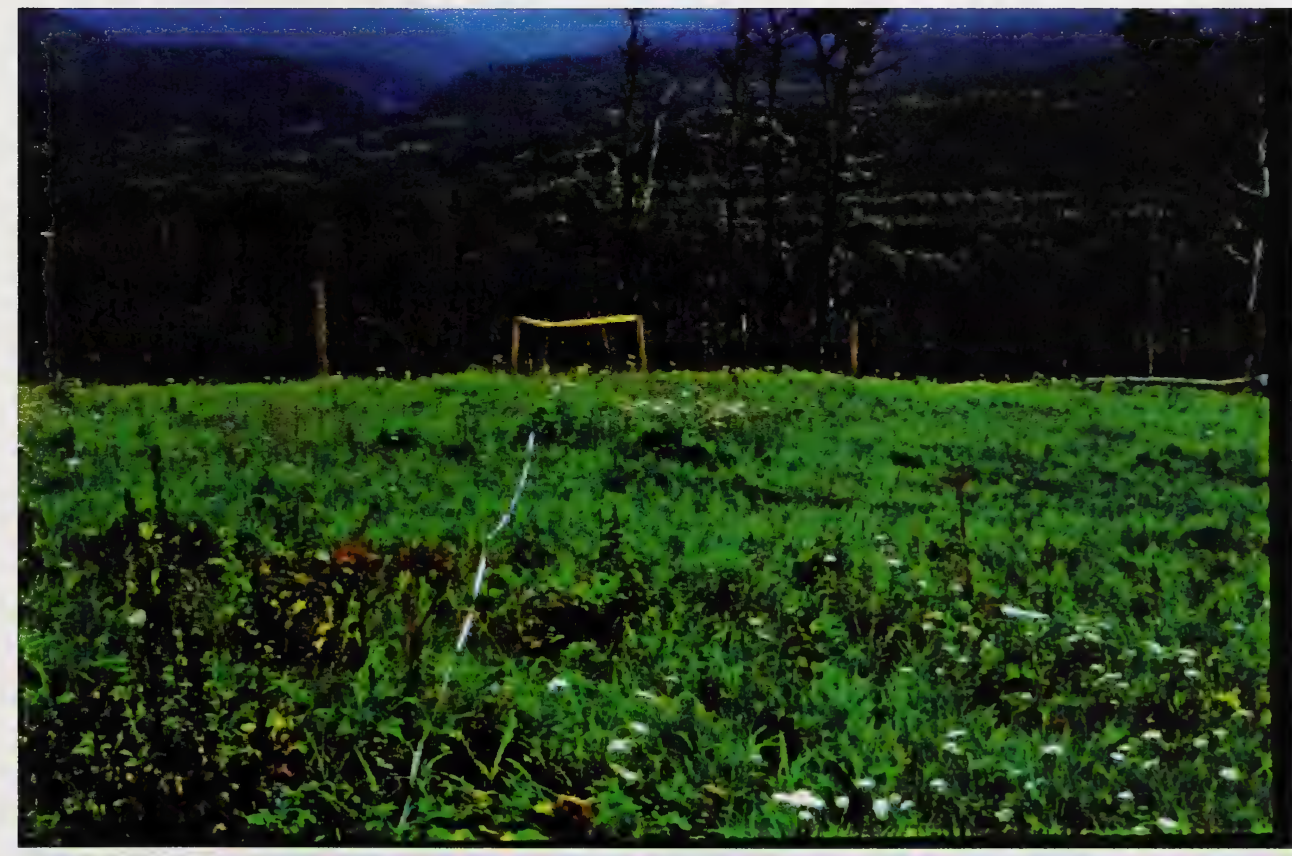





\section{Sulphur exclosure}

Region - Northeast Slopes; District - Foothills; Date established - 1998; Location Twp. 54, Rge. 8 Sec. 13 NE W6 (N 53.40.080, W119.02.196); Elevation-1634 m; Nutrients - mesotrophic; Drainage - well; Moisture - mesic - subhygric; Soil Classification - Orthic Regosol; Parent material - coarse textured fluvial deposits, adjacent to the Sulphur River; Description of Area - grazed sedge, slender wheatgrass meadow surrounded by willow and bog birch shrublands; Major species present, slender wheatgrass (Agropyron trachycaulum), sedge spp (Carex spp.), sheep fescue (Festuca saximontana), alpine milkvetch (Astragalus alpinus), mouse eared chickweed (Cerastium arvense), strawberry (Fragaria virginiana); Seral stage - young edaphic climax; Exclosure construction $-20 \times 30 \mathrm{~m}$ with wood and steel posts and two strands of barbed wire; Transect locations $-30 \mathrm{~m}$ long, read every $2 \mathrm{~m}$ starting at $2 \mathrm{~m}$, read on right hand side of tape from north to south, outside transect located $3 \mathrm{~m}$ on north side of the exclosure and read from south to north; This exclosure was established to monitor shrub encroachment and recovery of heavily grazed grassland meadows within Willmore Wilderness Park.

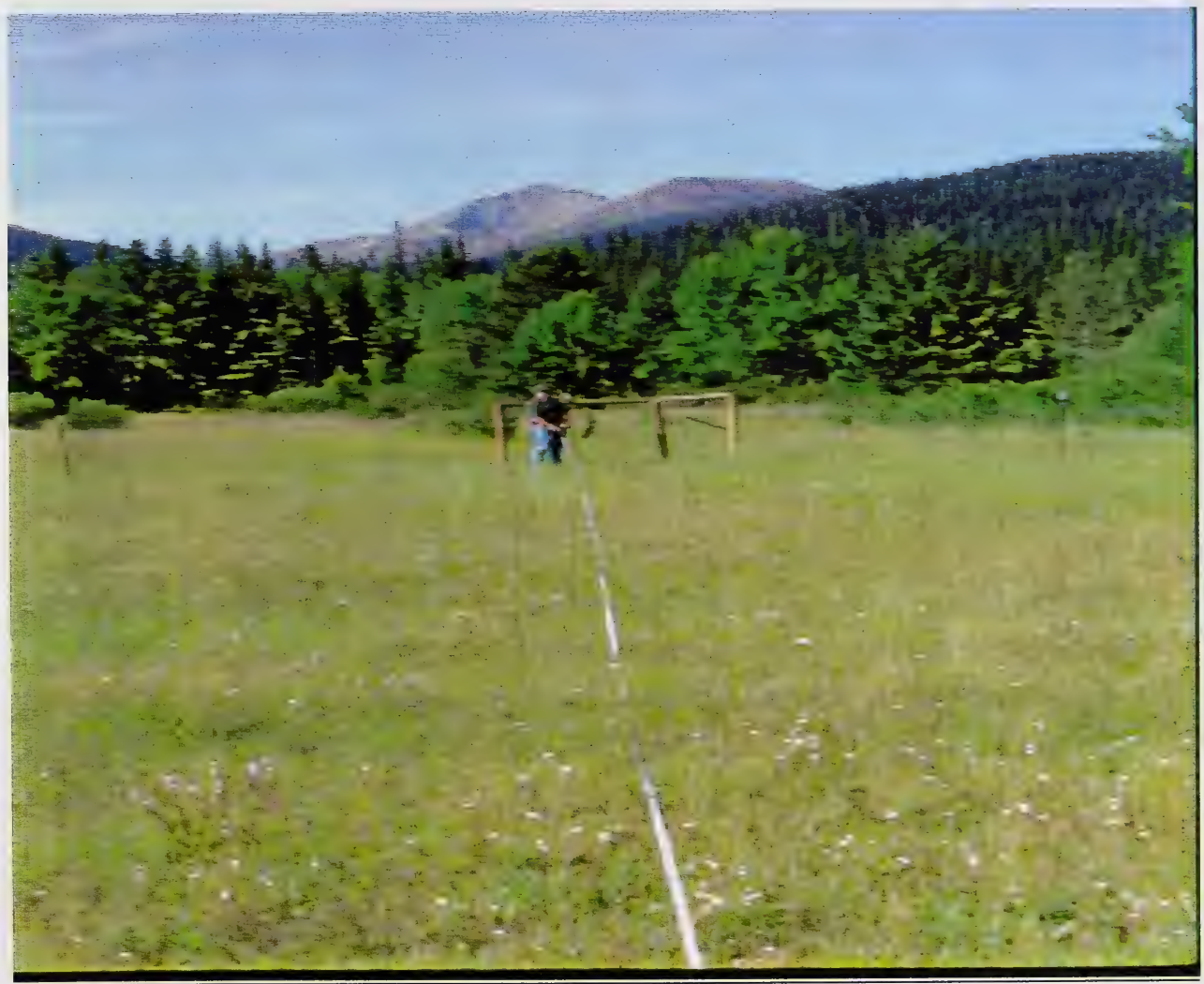





\section{Hayden ridge exclosure}

Region - Northeast Slopes; District - Foothills; Date established - 1976?; Location Twp. 55, Rge. 7 Sec. 21 NE W6 (N53.46.170 W118.58.608); Elevation - 1878 m; Aspect - $180^{\circ}$; Slope - 30\%; Nutrients - submesotrophic; Drainage - rapidly; Moisture subxeric; Soil Classification - non-soil; Parent material - coarse textured sandstone shale deposits, on ridge tops overlooking the Sulphur River; Description of Area - dry windswept snow free ridges; Major species present, white mountain avens (Dryas integrifolia, D. octopetala), bog sedge (Kobresia myosuroides), hairy wildrye (Elymus innovatus) alpine bistort (Polygonum viviparum), reindeer lichen (Cladina spp); Seral stage - mature edaphic climax; Exclosure construction - $20 \times 30 \mathrm{~m}$ with wood and steel posts and $8 \mathrm{ft}$ page wire; Transect locations $-30 \mathrm{~m}$ long, read every $2 \mathrm{~m}$ starting at $2 \mathrm{~m}$, read on right hand side of tape from northeast to southwest, the outside transect is located $3 \mathrm{~m}$ to the east of the exclosure and is read from south to north; This exclosure was established in the mid 1970's to monitor the effects of the bighorn sheep grazing in Willmore Wilderness Park

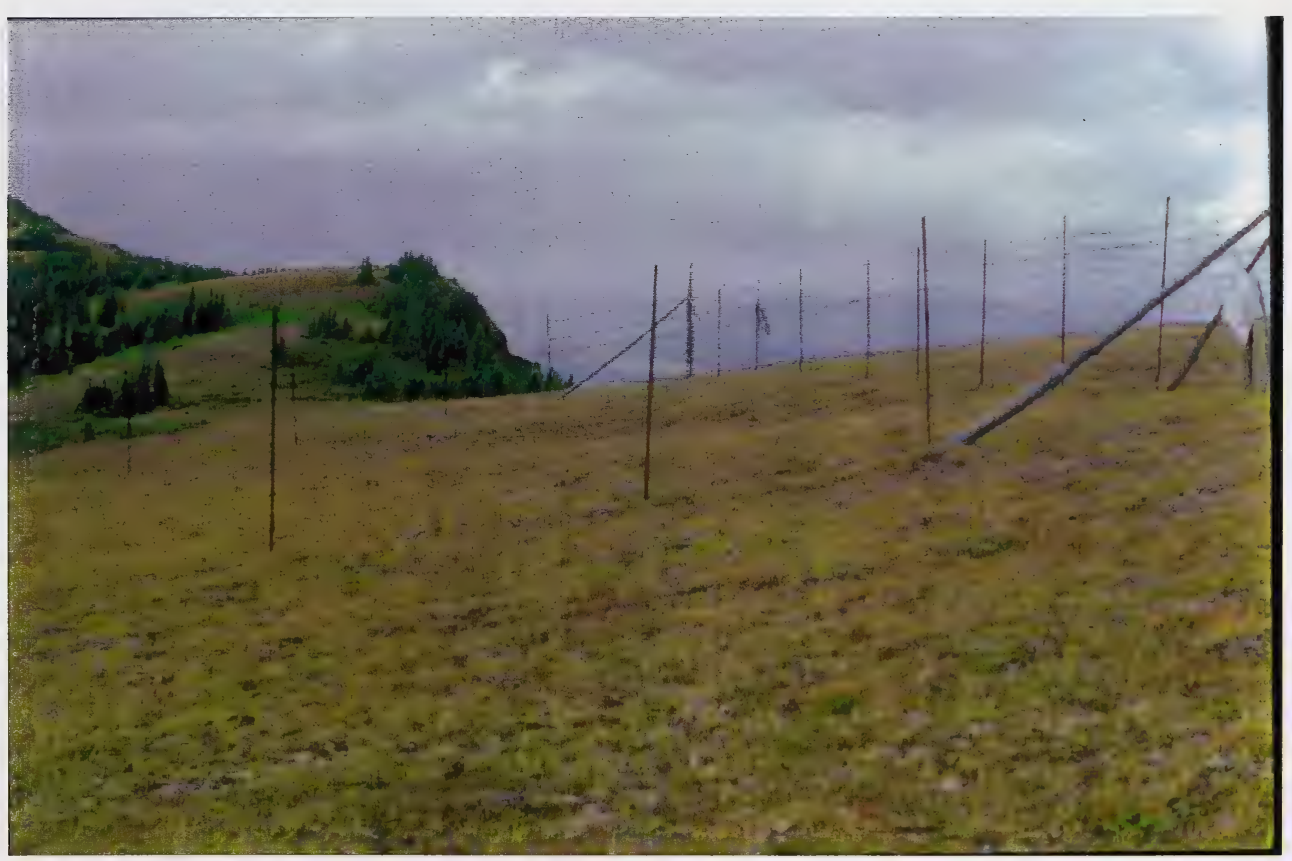





\section{APPENDIX B: \\ RANGELAND REFERENCE AREAS \\ WILLMORE WILDERNESS PARK}

The effect of a 1990 prescribed burn on species composition and forage production at Monoghan Flats 



\title{
RANGELAND REFERENCE AREAS
}

\section{WILLMORE WILDERNESS PARK}

\section{The effect of a 1990 prescribed burn on species composition and forage production at Monoghan Flats}

\author{
Prepared by
}

M.G. Willoughby 


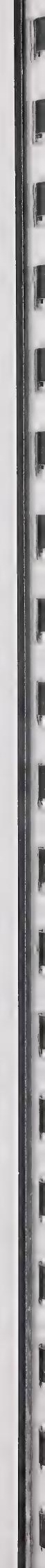




\section{APPENDIX C: \\ RANGELAND REFERENCE AREAS \\ WILLMORE WILDERNESS PARK}

The effect of a 1987 and 1994 prescribed burn on species composition and forage production at Kvass Flats 


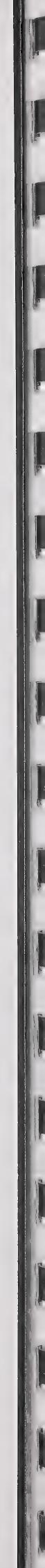




\title{
RANGELAND REFERENCE AREAS WILLMORE WILDERNESS PARK
}

The effect of a 1987 and 1994 prescribed burn on species composition and forage production at Kvass Flats

\author{
Prepared by
}

M.G. Willoughby

1999

Edmonton
Land and Forest Service

Forest Management Division 



\section{Introduction}

Willmore Wilderness Park is a 4597 square kilometer area in west-central Alberta located adjacent to the north of Jasper National Park and east of the British Columbia border. The majority of the use in the park each year is during the summer and fall and comes in the form of recreational horse use, commercial guides and outfitters, offering backcountry trail riding, camping and hunting. Recently, there has been concern expressed with the rate the native grasslands have been encroached by shrubs. This is a serious problem because most of the productive grasslands become inaccessible and less productive for both horses and wildlife. It is believed that the lack of fire within the park has allowed shrubs to expand onto the remaining grassland community types.

In 1999, permanent vegetation transects from a 1990 spring burn at Monoghan

Flats were recorded to determine the successional changes after buming on a Willow-Bog birch/Bog sedge-Sedge dominated community. The specific objectives of the original burn were to reduce the canopy cover of bog birch and willow and increase the available forage supply for wildlife in the area (MacCallum and Yakimchuk 1992). This report outlines the change in species composition and forage production from 1990 to 1999.

\section{Site characteristics}

Monoghan Flats is located beside the Sulphur River at the mouth of Monoghan Creek. It is located in sections NE14 and S1/2 23 of TWP 53 RGE 7 W6. The area is located within the Subalpine subregion (Strong and Thompson 1995) at an elevation of $1555 \mathrm{~m}$. The majority of vegetation in the Subalpine is dominated by seral lodgepole pine forests at lower elevations with Engelmann spruce and subalpine fir forests being common at higher elevations. At timberline dwarf spruce, and subalpine fir are typical of the transition to the Alpine subregion. Imperfectly drained bottomlands are dominated by willow, bog birch, sedge, tufted hairgrass and california oatgrass species and steep south facing slopes are often dominated by fescue, hairy wildrye, wheatgrass and junegrass species.

The area is located on a well-drained valley flood plain, bordered by coniferous trees on the west and the Sulphur River in the east. The soils at the site were classified as a Orthic Humic Regosol and there was $16.5 \mathrm{~cm}$ of alluvial material lying on top of outwash gravels. Periodic flooding of the valley bottom has prevented further soil development.

\section{Methods}

A $180 \mathrm{~m}$ baseline was established $5 \mathrm{~m}$ west of the horse trail that traverses Monoghan Flats. The baseline was divided into 3 segments and a, $60 \mathrm{~m}$ secondary transect was placed at right angles to the baseline at $36 \mathrm{~m}, 60 \mathrm{~m}$ and $132 \mathrm{~m}$ within each segment. Plots on the secondary transects were located in a systematic fashion every $4 \mathrm{~m}$ to facilitate remeasuring in subsequent years. The canopy cover of grasses and forbs were recorded in a 20x $50 \mathrm{~cm}$ Daubenmire frame and the canopy cover of shrubs was recorded in a $1 \times 1 \mathrm{~m}$ nested quadrat in 1999 and by the line-intercept method in 1990 and 1991 (MacCallum and Yakimchuk 1992).

A combination of both ordination (DECORANA) (Gauch 1982) and cluster analysis (SAS) were used to group the transects of different years. These techniques combined the sites based on the similarity of species composition. The groupings from cluster were used to determine the splits on the ordination figure. 


\section{Results}

The ordination of the Monoghan Flats transects with years grouped by cluster analysis is outlined in Figure 1. The first two axes in the ordination account for $29 \%$ and $4 \%$ of the variation in the species stand table, respectively. There is a distinct grouping of the transects in 1990, 1991 and 1999 (Figure 1). The 1999 transect represents a community that is dominated by willow and bog birch. In contrast the 1990 transect which was recorded the fall after the burn was dominated by willow, strawberry and slender wheatgrass. One year after the burn in 1991 the site was dominated by willow and slender wheatgrass and strawberry had declined (Table 1). Table 2 outlines the change in bog birch and willow cover from preburn to post burn in 1999. Burning caused willow and bog birch cover to decrease from 34 to $20 \%$ and 11 to $1 \%$, respectively. However, by 1999 both willow and bog birch cover had increased to preburn levels.

Table 3 outlines the change in forage production from 1991 to 1999. As shrub cover has increased there has been a dramatic decline in both forb and grass production from a high of $358 \mathrm{~kg} / \mathrm{ha}$ and $1065 \mathrm{~kg} / \mathrm{ha}$ in 1991 to a low of $246 \mathrm{~kg} / \mathrm{ha}$ and $132 \mathrm{~kg} / \mathrm{ha}$ in 1999. There has also been a corresponding increase in shrub production from $161 \mathrm{~kg} / \mathrm{ha}$ in 1991 to a high of $1200 \mathrm{~kg} / \mathrm{ha}$ in 1998 and $414 \mathrm{~kg} / \mathrm{ha}$ in 1999.

\section{Discussion}

Fire has played a dominant role in controlling brush expansion on these rangelands in the past and continued protection will probably allow the shrub growth to increase, resulting in further decline in forage productivity. Growth of the shrubs at the burn site declined moderately after the initial burn in the fall of 1990 and again in 1991 , but 9 years following the burn annual growth had increased to preburn levels. It would appear that periodic burning will be required to control willow expansion and increase forage productivity. In one study, burning a bog birch-willow shrubland 3 times in 9 years controlled shrub growth and increased forage production by over $40 \%$ compared to the unburned control (Bork et al. 1996).

In the absence of fire the plant community at Monoghan flats is slowly succeeding to a unproductive willow dominated community type. Willoughby and Smith (1997), found that many of these willow communities in the foothills of Alberta will succeed in the absence of disturbance to a community type that is dominated by willow. There is little forb and grass cover and low forage productivity for wildlife. If the primary resource of the vegetation is for wildlife production, then periodic burning is required to maintain the most productive plant community. If there is some resource that is valued that requires succession to a willow dominated shrubland then the site should be left undisturbed.

Historically, these shrubland communities in the foothills of West-Central Alberta have been burned and grazed by wild ungulates. Currently, the primary resource value for these rangelands is recreation and wildlife production. Periodic burning will be needed to maintain the resource values that are currently desired by society.

\section{Literature cited}

Bork, E., D. Smith and M.G. Willoughby. 1996. Prescribed burning of Bog Birch. Rangelands. 18(1): 4-7.

Gauch, H.G. 1982. Multivariate analysis in community ecology. Cambridge 



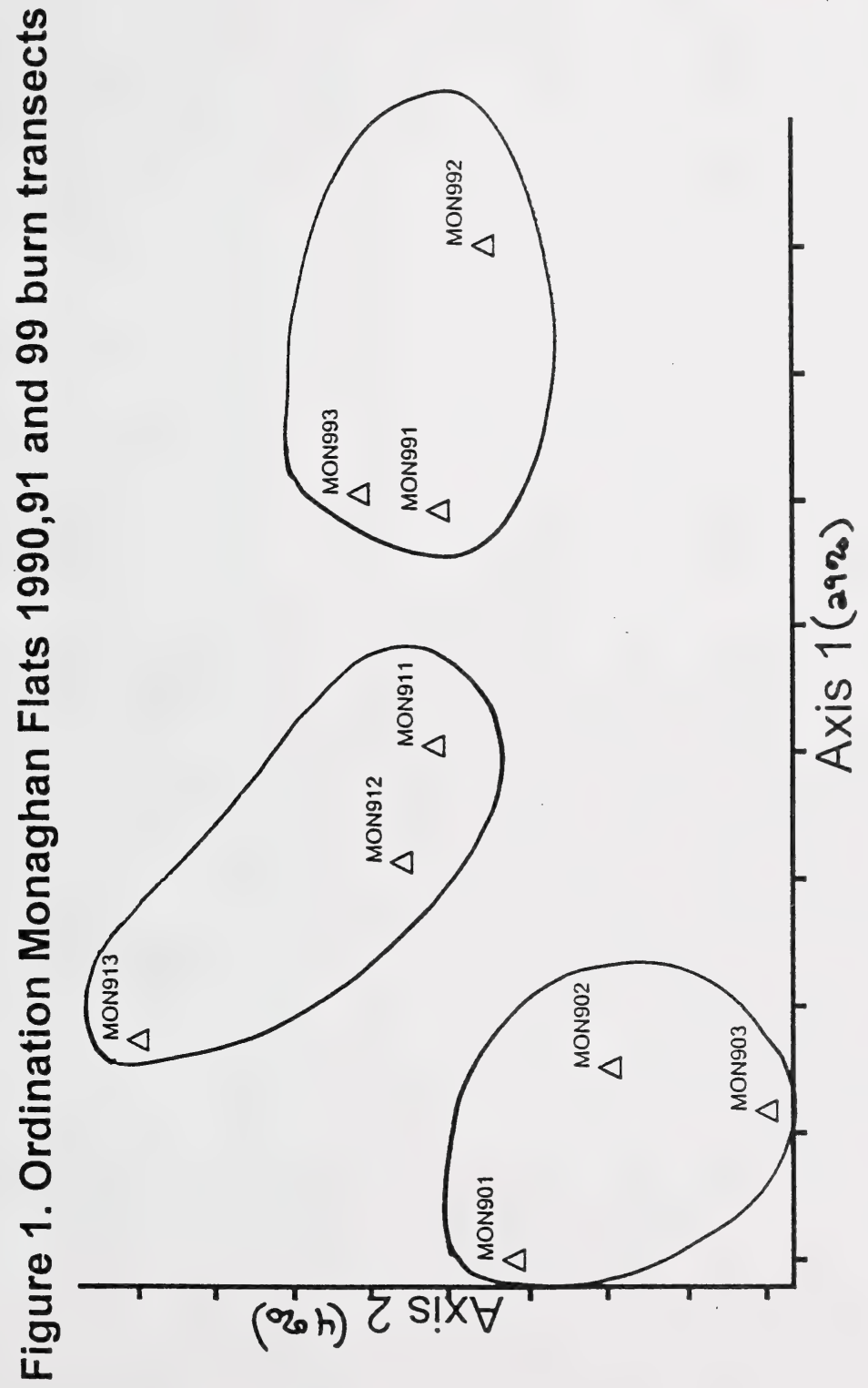



Table 1. Canopy cover (\%) of the dominant species on the 1990, 91 and 99 post burn transects at Monaghan Flats, Willmore Wilderness Park.

Species

1990

1991

1999

\section{Shrubs}

Smooth willow

(Salix glauca)

20

27

52

Myrtle leaved willow

(S. myrtillifolia)

8

Bog birch

(Betula glandulosa)

1

3

9

Forbs

Strawberry

(Fragaria virginiana)

19

10

6

Goldenrod

(Solidago multiradiata)

8

$\mathrm{T}$

Yarrow

(Achillea millefolium)

6

3

Woolly everlasting

(Antennaria lanata)

3

3

1

Fireweed

(Epilobium angustifolium)

2

3

5

Small flowered penstemon

(Penstemon procerus)

2

1

3

Graminoids

Hairy wildrye

(Elymus innovatus)

$\begin{array}{lllll}- & 4 & & 10\end{array}$

Slender wheatgrass

(Agropyron trachycaulum)

8

5

Bog sedge

(Kobresia myosuroides)

9

12

7

Sedge

(Carex spp.)

6

7

1

California oatgrass

(Danthonia californica) 

Table 2. Changes in shrub cover (\%) from preburn 1990 to post burn in 1990,1991 and 1999 at Monaghan Flats, Willmore Wilderness Park.

\section{Willow Bog birch}

\begin{tabular}{llll}
\hline May 1990 & T1 & 21 & 20 \\
(preburn) & T2 & 46 & 3 \\
& T3 & 36 & 11 \\
& Avg & 34 & 11 \\
Sept. 1990 & T1 & 24 & 0 \\
& T2 & 15 & 2 \\
& T3 & 18 & 1 \\
& Avg. & 20 & 1 \\
Sept 1991 & T1 & 35 & 4 \\
& T2 & 20 & 3 \\
& T3 & 26 & 2 \\
& Avg. & 27 & 3 \\
Aug. 1999 & T1 & & \\
& T2 & 55 & 10 \\
& T3 & 66 & 13 \\
& Avg. & 61 & 4 \\
\hline
\end{tabular}

Table 3. Forage production (kg/ha) at Monoghan flats in 1991, 1998 and 1999.

\begin{tabular}{llll} 
& 1991 & 1998 & 1999 \\
\hline Grass & 1065 & 536 & 246 \\
Forb & 358 & 286 & 132 \\
Shrub & 161 & 1200 & 414 \\
Total & 1584 & 2022 & 792 \\
\hline
\end{tabular}



University Press, Cambridge. 298 pp.

MacCallum, B. and R. Yakimchuk. 1992. Evaluation of the effects of one prescribed burn on a Willow/Bog birch meadow in the Subalpine ecoregion of Alberta. Forestry, Lands and Wildlife, Fish and Wildlife Division. Edmonton, AB.50pp.

Willoughby, M.G. and D. Smith. 1997. Range plant communities and carrying capacity for the Upper Foothills subregion. Dept of Environmental Protection. Forest Management Division. Edmonton, AB. Pub. No. T/356: 76pp. 
Appendix one:

Vegetation species lists for transects from 1990 to 1999. 



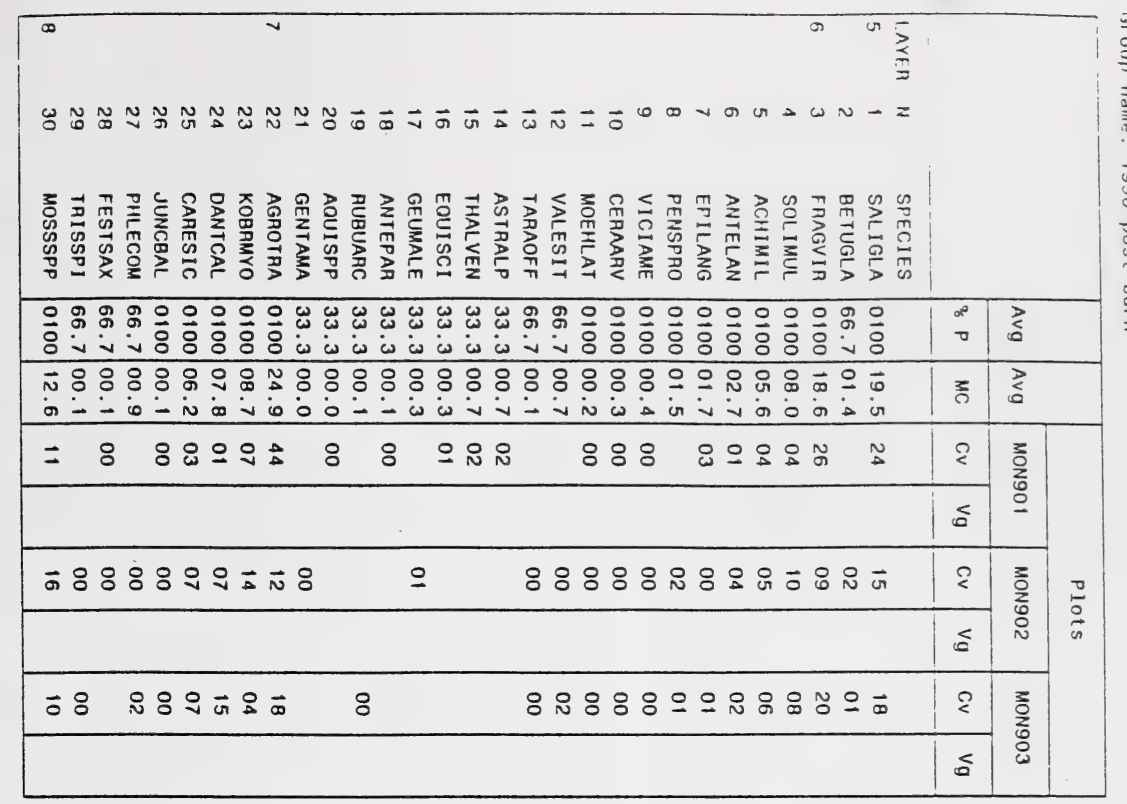




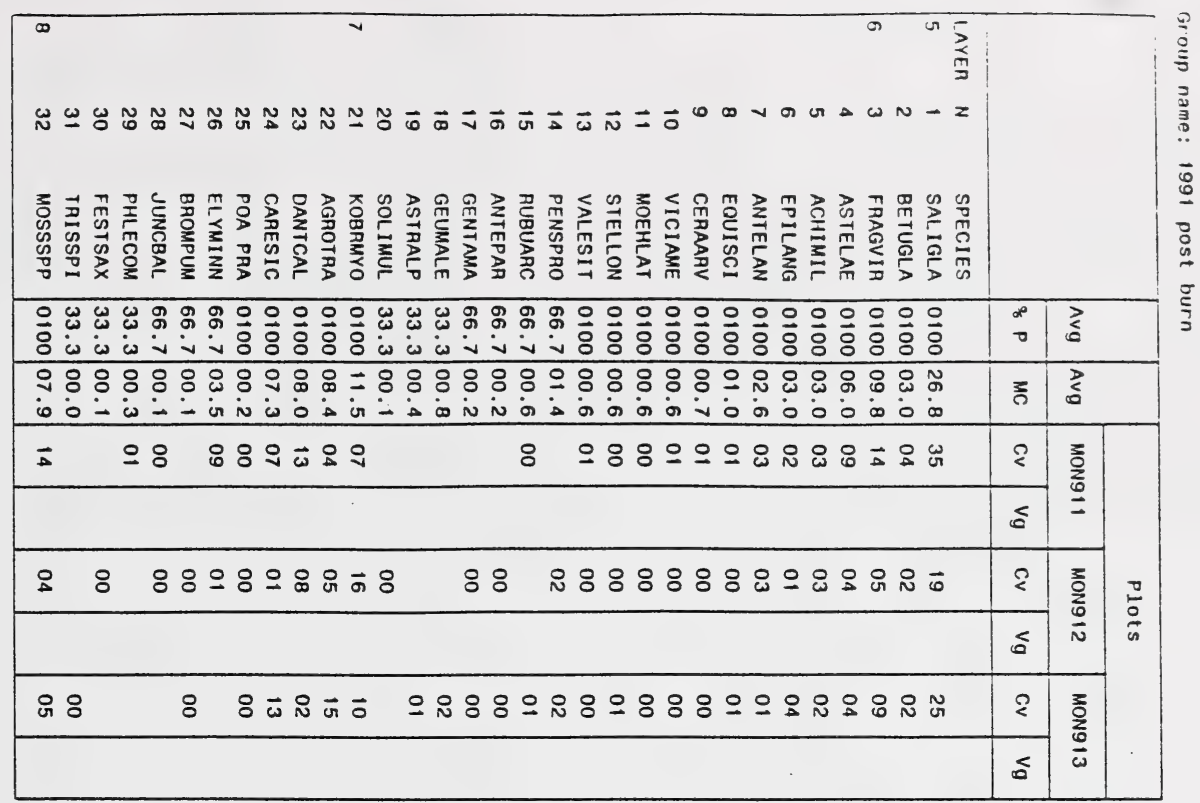





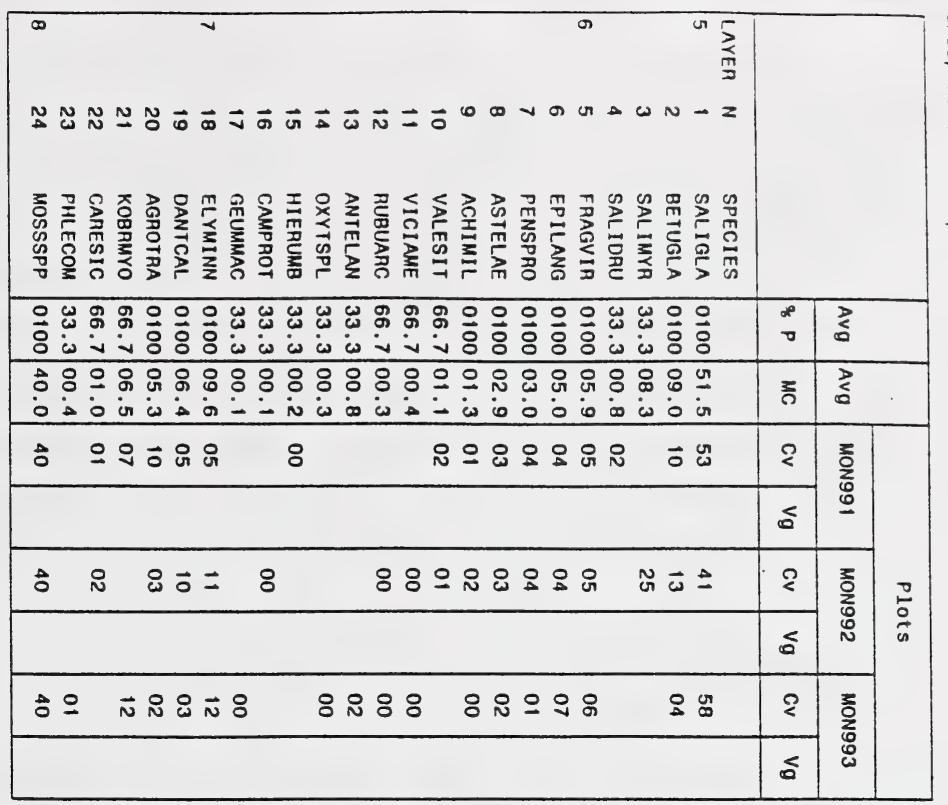





\section{Introduction}

The Kvass Flats area of Willmore Wilderness Park is an important foraging area for both horses and wildlife. It is situated close to the Hell's gate access to Willmore making it an important area for recreational horse use and commercial guides and outfitters, offering backcountry trail riding, camping and hunting. Heavy use and the establishment of non-native invaders have created a concern that there is insufficient forage for over-wintering wildlife. It is also believed that the lack of fire within the park has allowed aspen to expand onto many of the south facing grassland communities in the area. This has caused a further decline in available forage for both horses and wildlife.

In 1987 a prescribed burn was done in the aspen communities surrounding the open meadows in an effort to increase the forage supply and remove $80-90 \%$ of the willow and poplar growth. This burn was repeated and expanded in 1994. In 1999, an examination of forage production and species composition was made in the adjacent unburned aspen forest. This report outlines the change in species composition and forage production between the unburned aspen forest and area of the burn. It is too soon to examine the effects of horse grazing at the exclosure, which was erected in 1998.

\section{Site characteristics}

The Kvass Flats area is located beside the Smoky River at the mouth of Lawrence and Henrietta Creeks. It is located in sections SE4 of TWP 56 RGE 9 W6. The area is located within the Upper Foothills subregion (Strong and Thompson 1995) at an elevation of $1060 \mathrm{~m}$. This subregion is found elevationally below the subalpine and above the Lower Foothills subregions. It ranges in elevation from $1200-1500 \mathrm{~m}$ at lower latitudes and from 1000-1250 $\mathrm{m}$ at higher latitudes. It is dominated by closed canopy lodgepole pine forests with the potential climax species on reference sites being white spruce and black spruce. Deciduous communities are rare in this subregion. The cool climate severely restricts the growth of deciduous tree species (Strong and Leggat 1992). As a result aspen and balsam poplar are generally found on south facing slopes where the increased insolation permits colonization.

This subregion has a boreal climate which is modified by the Rocky Mountains. The average annual precipitation is $538 \mathrm{~mm}$ with over half the precipitation recieved in the summer months $\left(340 \mathrm{~mm}\right.$ ). The temperature averages $11.5^{\circ} \mathrm{C}$ in the summer and -6.0 ${ }^{0} \mathrm{C}$ in the winter. These temperatures are milder and not nearly as extreme as the other subregions within the Boreal forest and Foothills natural regions.

This site is located on a southwest facing slope midway up the slope from the Smoky River. The parent material is colluvial with a Orthic Humic Regosolic soil.

\section{Methods}

A $20 \times 30 \mathrm{~m}$ exclosure was established in the burned aspen forest in 1998. Two $30 \mathrm{~m}$ transects were placed inside and outside the exclosure. Every $2 \mathrm{~m}$ the canopy cover of grasses and forbs were recorded in a 20x $50 \mathrm{~cm}$ Daubenmire frame and the canopy cover of shrubs was recorded in a $1 \times 1 \mathrm{~m}$ nested quadrat. In 1999 a transect was also located in the adjacent unburned aspen in an effort to determine species composition prior to burning. The methodology to record the canopy cover of forbs and grass were similar to the transects in the burn. but the canopy cover of the trees was recorded once in a $10 \times 10 \mathrm{~m}$ quadrat. Half meter forage production clips were done inside and outside 

the exclosure and the adjacent unburned aspen forest.

A combination of both ordination (PCA) (Gauch 1982) and cluster anaivsis (SAS) were used to group the transects in the two treatments. These techniques comoined the sites based on the similarity of species composition. The groupings from cluster were used to determine the splits on the ordination figure. Species diversity was determined using the Shannon-Weiner index of species diversity (McCune and Mefford 1997).

\section{Results}

The ordination of the Kvass Flats transects with treatments grouped by cluster analysis is outlined in Figure 1. The first two axes in the ordination account for $80 \%$ and $2 \%$ of the variation in the species stand table, respectively. There is a distinct grouping of the burned and unburned transects (Figure 1). The burned transects represents a community that is dominated by rose, hairy wildrye and various forb species. In contrast the unburned transect represents an Aspen/Rose/Hairy wildrye dominated community type. Species richness, diversity and forage production are also much lower on the unburned site compared to burned site (Table 1).

Table 1 also outlines the change in canopy cover of selected species. The fires have had a dramatic effect on aspen. Reducing the cover of aspen from 55 to $1 \%$. There also was a dramatic increase in hairy wildrye cover from 12 to $32 \%$ and sedge cover to $6 \%$. Lindley aster and strawberry increased under burning, whereas, shrub cover was hardly affected remaining relatively uniform between the two treatments (Table 1). The increase in cover of grass and forbs from the unburned to burned site resulted in an increase in forage production from $1000 \mathrm{~kg} / \mathrm{ha}$ to over $1600 \mathrm{~kg} / \mathrm{ha}$.

Preliminary analysis from Fish and Wildlife staff indicate that deer use had remained stable on burned and unburned site between 1985 and 1989. They also found that elk and horse use had increased on the burned sites. Census data has also shown that the elk population has increased in the area surrounding the burn.

\section{Discussion}

In the past public agencies responsible for resource management have placed considerable emphasis on the suppression of tire in attempts to protect timber supplies, recreational pursuits, watersheds and rural communities (Bork et al. 1996). Ironically. decades of fire suppression have allowed shrubs and trees to encroach onto many of our native grasslands. This has resulted in loss in forage productivity and species diversity. Periodic burning of the aspen dominated communities in the Kvass Flats area will have to be done to prevent tree encroachment onto the native grasslands .

\section{Literature cited}

Bork, E., D. Smith and M.G. Willoughby. 1996. Prescribed burning of Bog Birch. Rangelands. 18(1): 4-7.

Gauch, H.G. 1982. Multivariate analysis in community ecology. Cambridge University Press, Cambridge. 298 pp.

McCune, B. and M.J. Mefford. 1997. PCORD: Multivariate Analysis of Ecological Data.Version 3.0. MJM software design. Gleneden Beach, Oregon. USA 



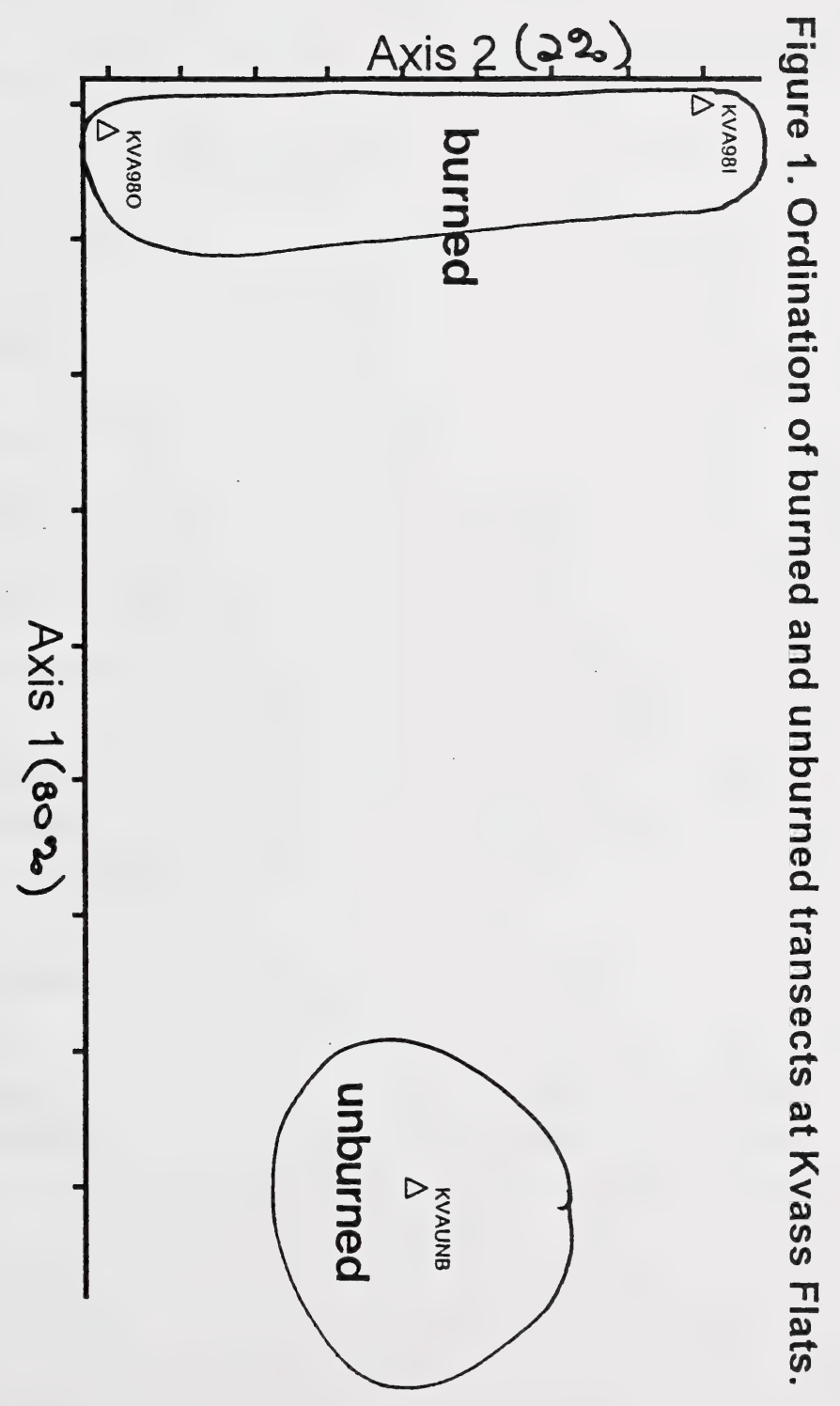



Table 1. Canopy cover (\%) of the dominant species in the burned and unburned transects at Kvass Flats, Willmore Wilderness Park.

Species

Burned

Unburned

Trees

Aspen

(Populus tremuloides)

1

55

White spruce

(Picea glauca)

0

7

Shrubs

Prickly rose

(Rosa acicularis)

8

6

Snowberry

(Symphoricarpos occidentalis)

3

3

Buffaloberry

(Shepherdia canadensis)

0

2

Forbs

Lindley's aster

(Aster ciliolatus)

Showy aster

(Aster conspicuus)

Strawberry

(Fragaria virginiana)

Fireweed

(Epilobium angustifolium)

Peavine

(Lathyrus ochroleucus)

Graminoids

Hairy wildrye

(Elymus innovatus)

Slender wheatgrass

(Agropyron trachycaulum)

Sedge

(Carex spp.)

9

1

Kentucky bluegrass

(Poa pratensis)

Species richness

Specis diversity

3

8

61

Production (kg/ha)

32

12

1

4

6

T

3

0

24

21

2.25

1.98

1645

1040 

Biophysical Attributes. Alberta Environmental Protection, Resource Data Division. Edmonton, AB. Pub. No. T/319.

Strong, W.L. and K.R. Leggat. 1992. Ecoregions of Alberta. Forestry, Lands and Wildlife, Resource Information Branch, Edmonton, AB. T/245. 



\section{Appendix one:}

Vegetation species lists for transects in 1998 and 1999. 



\begin{tabular}{|c|c|c|c|}
\hline 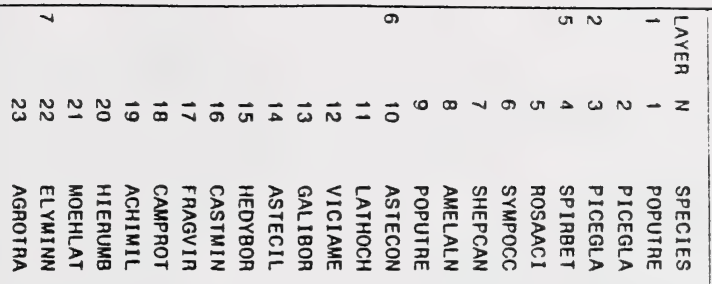 & & & \\
\hline 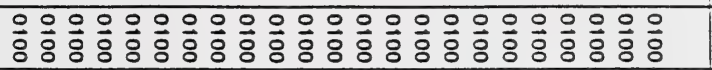 & क & \multicolumn{2}{|l|}{ ?̦ } \\
\hline 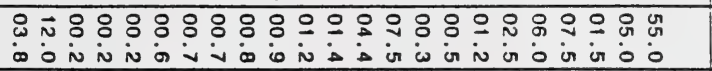 & 츠 & \multicolumn{2}{|l|}{ ב্ } \\
\hline 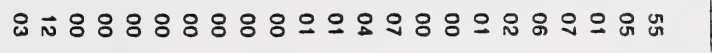 & 8 & \multirow{2}{*}{$\sum_{\substack{\mathbf{a} \\
\mathbf{z}}}^{\mathrm{r}}$} & \multirow{2}{*}{$\underset{0}{\circ}$} \\
\hline & 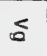 & & \\
\hline
\end{tabular}





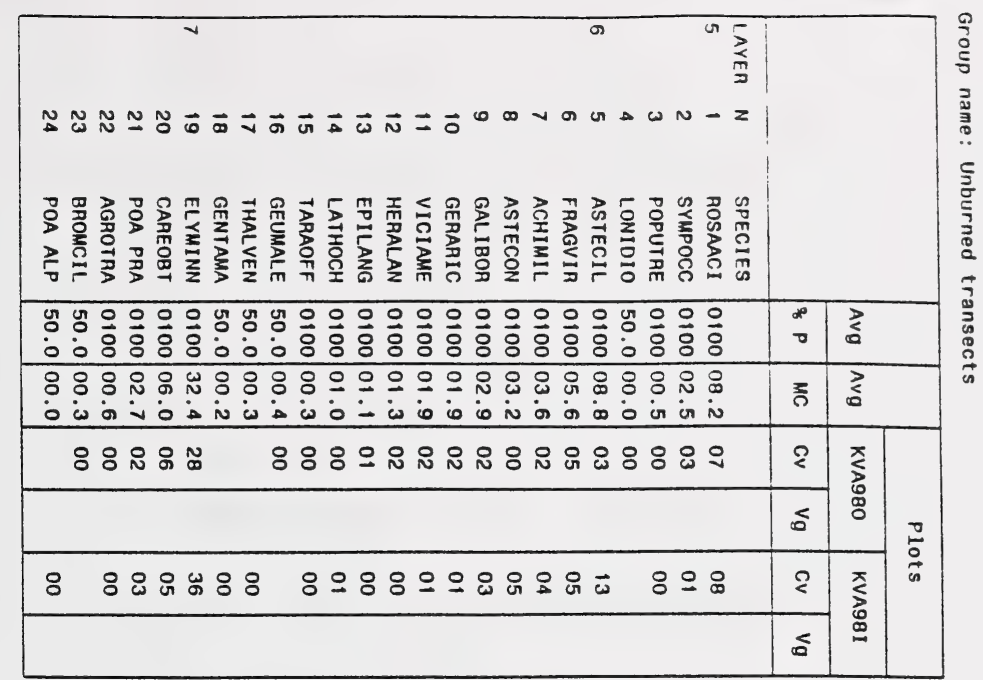





\section{APPENDIX D:}

ALBERTA NATURAL HERITAGE INFORMATION CENTER

WILLMORE WILDERNESS PARK

RARE PLANT MONITORING 

INTERIM REPORT

Joyce Gould, Alberta Natural Heritage Information Centre, Parks and Protected Areas Division, Natural Resources Services, Alberta Environment

$$
\text { Dr. Peter Achuff, Jasper National Park }
$$

Dr. René Belland, Devonian Botanic Garden, University of Alberta, Edmonton 



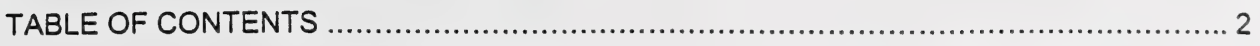

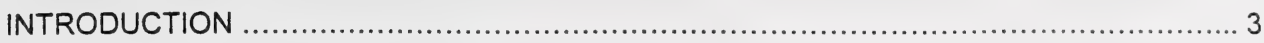

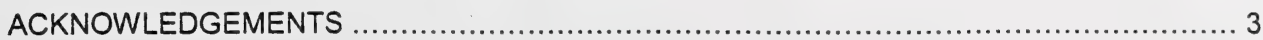

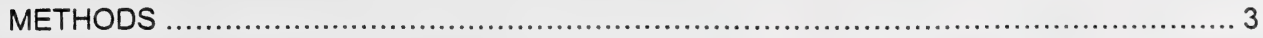

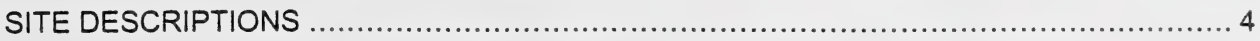

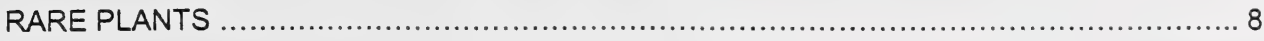

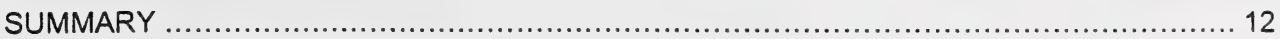

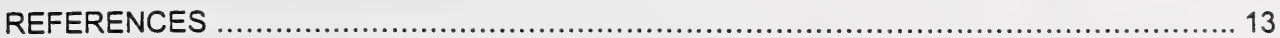

APPENDIX 1: ANHIC PLANT ELEMENT OCCURRENCES (EO'S) WILLMORE WILDERNESS PARK AND NORTHERN JASPER NATIONAL PARK

APPENDIX 2: LIST OF VASCULAR PLANTS OBSERVERED DURING THE COURSE OF THIS STUDY

APPENDIX 3: SAMPLE OF ELEMENT OCCURRENCE INFORMATION IN ANHIC (DOT 5457) 



\section{INTRODUCTION}

Rare species are the focus of several initiatives including the conservation of biodiversity and federal and provincial endangered species legislation. Knowledge of the distribution and population sizes of rare species is also important information that is useful for management planning purposes.

However, little attention has been paid to rare plant taxa within Willmore Wilderness Park and northern Jasper National Park. Documentation of rare plants has been done incidental to other surveys that focus on vegetation communities rather than rare species. Examples include surveys by the Alberta Ecological Survey in the mid-1970's and the ecological land classification initiated by the Alberta government in 1990. Additionally, the focus of most of these surveys was on vascular taxa and communities and there is little information on bryophytes other than to perhaps the most common species. George Pegg and Dr. John Packer of the University of Alberta collected some rare species in the 1960's. However, they were only able to access only a small portion of Willmore Wilderness Park and much of their information lacks details on population size and exact location.

Jasper National Park is the centre for moss diversity in the Alberta (Vitt and Belland 1997). Several rare bryophytes are known from there but adjoining Willmore Wilderness Park has never been surveyed for such species. The potential for rare taxa is certainly high given the proximity to Jasper and mosaic of lithologies. Rare vascular plants are also known from the area but the extent of their distribution and population sizes were largely unknown.

\section{ACKNOWLEDGEMENTS}

Dr. John Packer confirmed the identification of Artemisia furcata var. furcata and reviewed the collections of Viola. Mike Willoughby and Cam Lane, Land and Forest Service, Alberta Environment and the Foothills Model Forest provided logistical assistance. Staff of the Alberta Natural Heritage Information Centre assisted with various aspects of this project. Patsy Cotterill provided assistance with identification of vascular plants and processing of element occurrences, Drajs Vujnovic with mapping element occurrences, John Rintoul with production of occurrence information and Duke Hunter with map production. All photographs are those of Joyce Gould.

\section{METHODS}

Reconnaissance surveys for rare plants were conducted August 4-6 and 24, 1999. Rare plants are those on the Alberta Natural Heritage Information Centre list of "Plant Species of Special Concern", February 1999 (Gould 1999). Sites were accessed by helicopter with approximately 24 hours spent at each site. Attempts were made to relocate previously reported occurrences of rare species and to target new areas that had not been visited previously. Sites of various lithologies were visited. As many habitats as possible were surveyed for rare plants during each stop and a brief description of habitat and population size was made for each rare plant noted. Locations of rare species were noted with the Garmin 12 XL hand held GPS unit (NAD 27) and photographs of rare plants and/or their habitats were taken, where possible. Voucher specimens were collected for many taxa to confirm identification against annotated material at the University of Alberta herbarium and/or to document a new occurrence for Willmore Wilderness Park or Jasper National Park. These specimens will be deposited in the University of Alberta herbarium.

Joyce Gould conducted the surveys on August 4-6 and 24 and Dr. Peter Achuff, Jasper National Park assisted on August 6 and 24. Dr. René Belland, Devonian Botanic Garden, University of Alberta joined the party on August 24 to search for rare bryophytes. 

All occurrences of rare plants were entered into the Alberta Natural Heritage Information Centre databases. The tracking list for rare species was updated in November and December 1999 and species that had been noted for Willmore Wilderness Park and/or Jasper National Park that are now included on the updated tracking list are included in this report.

\section{SITE DESCRIPTIONS}

\section{Willmore Wilderness Park}

\section{Bury Ridge (11U 03993145935539 NAD 27)}

This site consists of a saddle near the top of ridge. The vegetation is primarily mesic tundra dominated by Salix reticulata and Dryas octopetala.

There are a series of patterned ground stone nets on the SE facing slope. The sparsely vegetated areas have Arnica angustifolia, Cerastium beeringianum, Erigeron trifidus, Festuca brachyphylla, Minuartia rubella, Potentilla nivea, Silene acaulis, the more heavily vegetated portions of the nets have Astragalus alpinus, Dryas octopetala, Festuca altaica, Polygonum viviparum and Salix reticulata.

Further upslope on a southwest-facing slope, there is an area of frost heaving with large boulders (11U 3993815935565 ). The vegetation is sparse consisting of scattered individuals of various alpine species.

The vegetation at the top of the ridge is primarily rocky tundra.

Rare plants noted from this site include Antennaria monocephala, Anthoxanthum monticola, Arabis lemmonii, Artemisia borealis, Artemisia furcata var. furcata, Carex incurviformis var. incurviformis, Erigeron trifidus (approx. 100 plants), Festuca altaica, Minuartia elegans, Oxytropis campestris var. davisii, Pedicularis capitata, Pedicularis flammea, Pedicularis lanata, Saxifraga flagellaris (approximately 70 plants) and Silene involucrata.

Most of the Saxifraga flagellaris were noted from the top of the ridge. Pedicularis lanata occurs primarily near the top of the slope and at the top of the saddle-it is not as common midslope.

The lithology of the area is sandstone, silty shale, shale, conglomerate of the Luscar Formation which is Lower Cretaceous in age.

Pika were heard at this site and a track of caribou was noted.

\section{Childear Mountain (11U 03523615951128 )}

Dryas integrifolia-lichen tundra occurs on the west-facing slope of the saddle. There is a turfy area at the base of the slope and Salix reticulata-Salix arctica tundra dominates. This grades into Dryas integrifolia-Salix arctica tundra. The lower portions of the saddle have Dryas octopetalalichen tundra. Periglacial features such as stripes are present.

Rare plants from this site include Antennaria monocephala, Campanula uniflora, Draba porsildii, Oxytropis campestris var. davisii, Pedicularis capitata and P. lanata and Saxifraga nivalis.

The geology of this area is argillaceous limestone, calcareous shale, grey dolostone, crinoidal limestone and cherty dolostone of the Mississippian Banff Formation and Rundle Group and dark brown silty shale, siltstone, sandstone, and calcareous sandstone of the Triassic Sulphur Mountain Formation. 



\section{Eagle's Nest (11U 04003985927123 )}

The primary vegetation at this site is Dryas integrifolia tundra although some stone stripes are evident and Cassiope tetragona forms mats in late lying snowbed areas.

Hummocks dominated by Dryas integrifolia and Thuidium sp. occur on a north-facing slope.

Several rare species including Braya purpurascens, Draba porsildii, Erigeron trifidus, Festuca altaica, Minuartia elegans, Papaver kluanensis, Pedicularis capitata, Pedicularis flammea, Pyrola grandiflora, and Salix alaxensis occur at this site.

The geology of the areas is sandstone, silty shale, shale, conglomerate of the Lower Cretaceous Luscar Formation and sandstone, sandy shale, carbonaceous shale of the Jurassic and (?) Cretaceous Nikanassin Formation. There is also black fissile shale and silty shale and crossbedded sandstone, siltstone and silty shale of the Upper Cretaceous Kaskapau and Cardium Formations.

\section{Eagle's Nest Cabin (11U 04005505929650 )}

The valley bottom is dominated by shrub meadows of Betula glandulosa-Salix drummondiana-S. glauca-S. myrtillifolialFestuca altaica. Festuca altaica was the only rare species noted from this site.

The geology of this area is a complex of dolomitic limestone of the Palliser Formation, grey limestone and dolostone of the Cairn and Southesk Formation and argillaceous limestone, calcareous shale and dolostone of the Banff Formation.

\section{Hayden Ridge (11U 03698075959410$)$}

The vegetation of the ridge top is primarily Dryas octopetala tundra although Dryas integrifoliaKobresia myosuroides tundra is also present.

Rare plants noted from this site include Anthoxanthum monticola, Festuca altaica, Pedicularis flammea and $P$. lanata.

The geology of the ridge top is black fissile shale and silty shale of the Kaskapau Formation and crossbedded sandstone, siltstone and silty shale of the Cardium Formation.

\section{Monoghan Flats (11U 03734205938629 )}

The vegetation along the valley bottom is a Salix glauca/Kobresia myosuroides community type. No rare species were noted from this site.

The geology of Monoghan Flats is primarily argillaceous limestone, calcareous shale, grey dolostone, crinoidal limestone and cherty dolostone of the Mississippian Banff Formation.

\section{North of Kvass Creek, West of Sulphur River (11U 03630555952774 )}

The vegetation of this site is primarily Dryas integrifolia-Salix reticulata tundra. Periglacial features such as stone nets and stripes are evident. 

Rare species noted from this site include Antennaria monocephala, Campanula uniflora, Draba porsildii, Erigeron trifidus, Minuartia elegans, Papaver kluanensis, Pedicularis capitata, Pyrola grandiflora, Saxifraga nelsoniana ssp. porsildiana and Saxifraga nivalis.

The geology of this site is sandstone, sandy shale and carbonaceous shale of the Jurassic and (?) Cretaceous Nikanassin Formation.

\section{Persimmon Range, Willmore (11U 03962395929064 )}

The geology of this site is a complex of sandstone, silty shale, shale and conglomerate of the Luscar Formation and argillaceous limestone, calcareous shale of the Banff Formation, grey dolostone, crinoidal limestone and cherty dolostone of the Rundle Group and dolomitic limestone of the Palliser Formation. Periglacial features such as stone stripes are evident.

The vegetation on the stripes is primarily Dryas integrifolia tundra although late lying snowbeds with Cassiope tetragona and mesic tundra with Salix reticulata are also present. Dryas octopetala tundra occurs on a south-east facing slope.

Rare plants found at this site include Antennaria monocephala, Campanula uniflora, Draba porsildii, Erigeron trifidus, Festuca altaica, Minuartia elegans and Pedicularis lanata.

\section{Resthaven, Willmore Wilderness Park (11U 03382915928024$)$}

Two small lakes are situated at the top of a saddle on the north side of the pass. The vegetation on the saddle is a complex of mesic and dry tundra with Cassiope mertensiana, Lycopodium alpinum, lichen and moss and Dryas octopetala-lichen tundra. There are late snowbed communities dominated by either Carex nigricans or Salix arctica-moss. Small depressions with water provide habitat for species such as Eriophorum scheuchzeri, E. polystachion, Carex nigricans, C. spectabilis and Juncus drummondii. A small creek bisects the saddle and species such as Artemisia norvegica, Aulocomnium sp., Caltha leptosepala, Erigeron peregrinus, Juncus drummondii, Polygonum viviparum, Potentilla diversifolia, Saxifraga lyallii and Sibbaldia procumbens occur along its edge. There is a considerable amount of consolidated talus along the north slope of the valley. The rocks are covered in lichen-primarily Rhizocarpon geographicum with Racomitrium sp. and Cetraria spp. growing in between the rocks.

Rare plants noted from this site include Antennaria monocephala, Anthoxanthum monticola, Gentiana glauca and Saxifraga ferruginea. An interesting Viola was collected from this site. Dr. John Packer, University of Alberta, has reviewed the specimen and has indicated that it requires verification by an authority in this genus. It may be Viola epipsila but this taxon is difficult to separate from $V$. palustris. If the specimen were determined to be $V$. epipsila, it would represent the first record of the species for Alberta.

The geology of this area is primarily silty argillite and mudstone, feldspathic sandstone and granule conglomerate of the Cambrian Upper Miette Group and massive quartz sandstone, siltstone and minor pebble conglomerate of the Cambrian McNaughton Formation.

\section{Sulphur Creek (11U 03654275948201 )}

This site is situated along the valley bottom of Sulphur Creek.

No rare plants were observed at this site. 

The geology of the valley bottom is primarily black shale, silty shale and siltstone of the Jurassic Fernie Group.

\section{West of Adam's Creek (11U 03879785952827 )}

The vegetation here is primarily Dryas integrifolia tundra. Rare plants found at this site include Campanula uniflora, Festuca altaica, Oxtryopis campestris var. davisii, Pedicularis flammea, $P$. lanata and Saxifraga flagellaris.

The geology of this area is a complex of argillaceous limestone, calcareous shale, grey dolostone, crinoidal limestone and cherty dolostone of the Mississippian Banff Formation and undivided sandstones, shales and limestones of the Triassic Spray River Group.

\section{Jasper National Park}

\section{Azure Lake, Jasper National Park (11U 03646245926385 )}

Dryas octopetala tundra dominates the south-facing slope of the valley. Areas of Salix reticulata tundra and Salix arctica tundra also occur. Late-lying snowbeds are also present and here Antennaria lanata and Cassiope mertensiana dominate the vegetation.

Rare plants noted from this site include Antennaria monocephala, Anthoxanthum monticola, Carex glacialis, Gentiana glauca, Huperzia halaekalae and Saxifraga nelsoniana ssp. porsildiana.

The geology of the site is quartz sandstone and siltstone of the McNaughton Formation (Cambrian).

Eight caribou were noted southeast of the area.

\section{Topaz Lake Area, Jasper National Park (11U 03744815912875 )}

The vegetation at this site is primarily mesic tundra of the upper subalpine-alpine. Heath of Cassiope mertensiana and Phyllodoce empetriformis is common. Small pools in the area contain species such as Sphagnum sp. and Caltha leptosepala.

Rare plants noted from this site include Cardamine bellidifolia, Gentiana glauca, Saxifraga ferruginea and Viola pallens. A Potentilla collected here may be $P$. multisecta, a rare species. $P$. multisecta is quite similar to $P$. diversifolia, a common species in this habitat. Further determination of the specimen is needed.

The geology of this site is quartz sandstone, siltstone and pebble conglomerate of the Cambrian McNaughton Formation.

Three caribou were seen on site. 



\section{RARE PLANTS}

\section{Species accounts}

A brief summary of each rare species encountered in this survey is provided below. Species accounts are in alphabetical order along with their provincial and global ranks based on The Nature Conservancy ranking system. A brief description of habitat and known Alberta and global distribution is also provided for each species.

Taxonomy and nomenclature for vascular plants follows Moss (1983) unless more recent treatments such as Flora of North America are available.

Several mosses were collected during the course of this study however, these have not been identified. Identifications will be checked against the tracking list and occurrences of all rare species will be entered into the ANHIC databases.

\section{Antennaria monocephala DC (one-headed everlasting)}

G4G5/S2

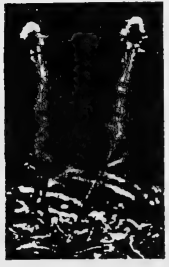

Antennaria monocephala is a perennial herb of alpine slopes and ledges. It is often associated with the margins of solifluction lobes or unstable gravelly tundra (Bayer 1993). In Alberta, it is known from Willmore Wilderness Park south to Banff National Park. The global distribution of this species is Alaska, Yukon, NWT, Nunavut, western Greenland, Labrador, BC, Alberta, Montana and Wyoming (Bayer 1993).

\section{Anthoxanthum monticola (Bigelow) Y. Schouten \& Veldkamp. (alpine sweet grass) G5/S2}

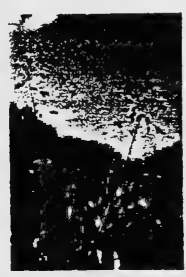

This perennial grass, also known as Hierochloe alpina (Sw.) R.\& S., grows on dry alpine slopes. In Alberta, it is known only from the northern Rockies such as Jasper National Park, Willmore Wilderness Park and the Cardinal Divide area. It has a circumpolar distribution and is known from Alaska, Yukon, NWT, Nunavut, $B C$ and Alberta.

\section{Arabis lemmonii S. Wats. (Lemmon's rock cress)}

\section{G5/S2}

This is a perennial herb known in Alberta from theRockies from Waterton north to Willmore Wilderness Park. It is found on alpine slopes (Moss 1983). It is a North American species distributed from Yukon, BC, AB south to California and Colorado (Moss 1983).

\section{Artemisia furcata Bieb. var. furcata (forked wormwood)}

G4T?/S1

Artemisia furcata var. furcata is a perennial herb known in Alberta from a 1975 collection from Caw Ridge. The discovery of this plant in Willmore represents the second record of this species for the province. It grows on rocky alpine slopes and is known from eastern Asia, Alaska, Yukon, NWT, Alberta and Washington. 



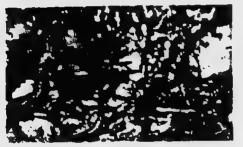

Alpine braya is a perennial member of the mustard family that grows on alpine screes (Moss 1983). It has a circumpolar distribution and in Alberta is known from the northern Rockies south to Kootenay Plains.

Campanula uniflora L. (alpine harebell)

G4/S2

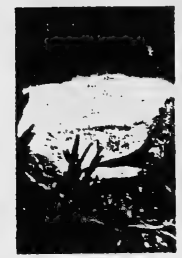

Alpine harebell is a perennial member of the bluebell family. It grows on alpine slopes (Moss 1983) and is known in Alberta from Willmore Wilderness Park south to Plateau Mountain. It has a circumpolar but scattered distribution.

\section{Cardamine bellidifolia L. (alpine bitter cress)}

G5/S2

Alpine bitter cress is a perennial herb that is known from the Rockies--Banff north to Jasper National Park. The habitat is moist alpine banks and ledges (Moss 1983). It has a circumpolar distribution occurring from Alaska, Yukon, NWT, Nunavut, Quebec, Labrador, BC, Alberta, south to California (Moss 1983).

Carex glacialis Mack. (glacier sedge)

G5/S2

Glacier sedge is a perennial plant of alpine slopes (Moss 1983). It has a circumpolar distribution and in Alberta is known primarily from the central Rockies. This is the first record for Willmore Wilderness Park.

\section{Carex incurviformis var. incurviformis Mack. (seaside sedge)}

G4G5T?/S2

This perennial sedge is also known as Carex maritima Gunn. The habitat is gravelly alpine areas (Moss 1983). It is known in Alberta in the Rockies from Willmore Wilderness Park south to Banff National Park. There is a record for the Edmonton river valley but this is likely to be the result of a chance event and the population has since been extirpated. It has a circumpolar distribution.

\section{Draba porsildii Mulligan (Porsild's whitlow-grass)}

G3G4/S2

Draba porsildii is a perennial herb of shaly talus and gravel slopes and upland alpine meadows of the Rocky Mountains (Rollins 1993). In Alberta, is it known from four locations in Willmore Wilderness Park south to the Castle River area north of Waterton. These are the first records for Willmore Wilderness Park. Its global distribution is Colorado to NWT and Yukon (Rollins 1993).

\section{Erigeron trifidus Hook. (trifid-leaved fleabane)}

\section{G2?Q/S2}

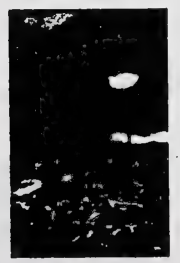

Erigeron trifidus is a perennial herb of alpine slopes that is closely related to $E$. compositus and $E$. lanatus. It was first described in 1834 by Hooker based on material collected by Drummond in 1826 from the Rocky Mountains of Alberta. Packer (1983) states that the type material is probably from the Persimmon Range (Willmore Wilderness Park). In Alberta, it is known primarily from the northern Rockies (Jasper National Park, Willmore Wilderness Park, Cardinal Divide area) although it has also been found recently in Waterton Lakes National Park (Achuff 1997). Globally, it is known only from BC and Alberta. 
Festuca altaica Trin. was formerly included in Festuca scabrellaTorr.. It is known from BC, Yukon, NWT, Alaska, Michigan, Quebec, Newfoundland, eastern Siberia and central Asia (Aiken and Darbyshire 1990). In Alberta, it is known only from the northern Rockies.

Gentiana glauca Pallas (alpine gentian)

G4G5/S2

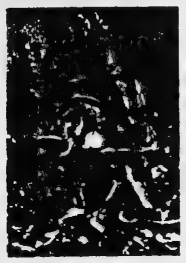

Gentiana glauca is a perennial herb of moist alpine slopes and meadows (Moss 1983). In Alberta, it is known from Banff and Jasper National Parks, Willmore Wilderness Park and Whitegoat Wilderness Area. The typical flower colour is blue but green-flowered forms were also found at the Resthaven site during the course of this study.

\section{Huperzia halaekalae (Brackenridge) Holub (alpine fir-moss)}

G4?/S2

This species was formerly included within Lycopodium selago L.. It is a species of exposed, moist meadows and mossy heaths of the alpine and subalpine (Wagner and Beitel 1993). In Alberta it is known from Banff and Jasper National Parks, Whitegoat and Siffleur Wilderness Areas and the Cardinal Divide area. This is the first report of this taxon from Willmore Wilderness Park. Globally, it is known from AB, BC, Yukon, Alaska, Colorado, Montana, Washington, Wyoming, Asia and Hawaii (Wagner and Beitel 1993).

\section{Minuartia elegans (Cham. \& Schlecht.) Schischk. (purple alpine sandwort) G4G5/S1}

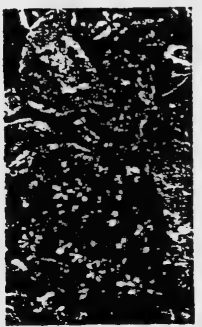

Minuartia elegans is a perennial herb that is restricted to moist calcareous alpine slopes. In Alberta, it is known only from Willmore Wilderness Park. The range of this species is eastern Siberia, Alaska, Yukon, BC, AB and NWT.

Oxytropis campestris var. davisii is in the Flora of Alberta (Moss 1983) as O. jordallii. Recent work by $\mathrm{S}$. Welsh has shown that true $O$. jordallii is a northern taxon (Alaska, Yukon and NWT). Oxytropis campestris var. davisii is a species of gravelly sites in the northern Rockies and foothills and is known from BC, Alberta and NWT (S. Welsh pers. comm.). In Alberta, this taxon is known only from the northern Rockies and foothills. This is the first record for Willmore Wilderness Park.

\section{Papaver kluanensis D. Love (alpine poppy)}

\section{G3?Q/S2}

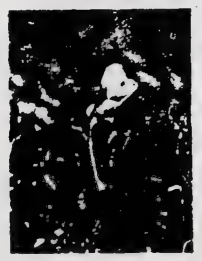

Papaver kluanensis is a perennial herb of shaly alpine slopes (Moss 1983). In Alberta it is known from the Rockies of Willmore Wilderness Park, south to Banff National Park. This collection is the first record for Willmore Wilderness Park. 


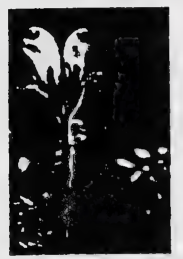

This perennial herb is restricted to calcareous alpine slopes (Moss 1983). In Alberta, it is known from Willmore Wilderness Park south to Banff National Park. It is a circumpolar species.

\section{Pedicularis flammea L. (flame-coloured lousewort)}

This perennial herb is restricted to calcareous alpine slopes (Moss 1983). It is known in $A B$ from the central Rockies (Moss 1983). The range of this species is Greenland, Iceland, Lapland, Nunavut, Newfoundland, Hudson Bay, James Bay, southern Labrador, Alberta and Gaspé (Moss 1983).

Pedicularis lanata Cham. \& Schlecht. (woolly lousewort)

G4G5/S2

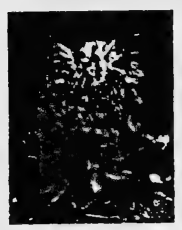

Pedicularis lanata is a perennial herb that grows on alpine slopes (Moss 1983). In Alberta it is known only from the northern Rocky Mountains such as at Cardinal Divide. It is a circumpolar species.

\section{Pyrola grandiflora Radius (Arctic wintergreen)}

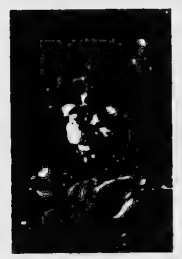

Arctic wintergreen is a perennial herb of alpine slopes and tundra (Moss 1983). It has a circumpolar distribution and in Alberta is known from the northern Rockies south to Banff National Park and from the Canadian Shield of the northeastern portion of the province.

\section{Salix alaxensis (Anderss.) Coville (Alaska willow)}

Salix alaxensis is a woody, prostrate shrub that occurs on alpine slopes (Moss 1983) and along gravelly river courses (pers. obs.). Most collections in Alberta are from the Front Ranges of the Rocky Mountains and it is known from Willmore Wilderness Park south to Banff National Park. This is the first record of this species for Willmore Wilderness Park.

\section{Saxifraga ferruginea Graham (saxifrage)}

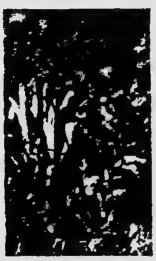

Saxifraga ferruginea is an herbaceous perennial that grows in moist alpine banks and ledges (Moss 1983). It is known from the Rockies from Jasper south to just north of Waterton Lakes National Park. It is not currently known from Willmore Wilderness Park but should be looked for. 



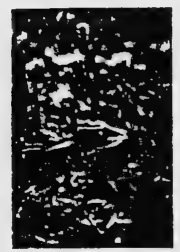

Saxifraga flagellaris is a perennial herb of calcareous turfy alpine slopes and ridges (Moss 1983). In Alberta, it occurs from Willmore Wilderness Park south to Banff National Park. It is a circumpolar species known from Asia, Alaska, Yukon, Northwest Territories, Nunavut, BC and Alberta (Moss 1983).

Saxifraga nelsoniana D. Don ssp. porsildiana (Calder \& Savile) Hult. (Nelson's saxifrage) G5T3T4/S2

Nelson's saxifrage is a perennial herb known in Alberta primarily from the northern Rockies although there is an isolated occurrence in Banff National Park. It is a species of alpine habitats (Moss 1983) and it is known from Asia, NWT, Nunavut, BC and Alberta south to Oregon. All of the Alberta material of Saxifraga nelsoniana is referrable to subspecies porsildiana.

\section{Saxifraga nivalis L. (alpine saxifrage)}

G4G5/S2

This is a perennial herb of alpine slopes and ridges (Moss 1983). In Alberta it is known only from the northern Rockies (Jasper and Cardinal Divide areas). This species has a circumpolar distribution occurring in Alaska, Nunavut, Labrador, BC, Alberta and Quebec (Moss 1983).

\section{Silene involucrata (Cham. \& Schlecht.) Bocquet (alpine bladder catchfly) G5/S1S2}

This species is also known as Silene furcata Raf.. It is a perennial herb of the Rockies and foothills known from Willmore Wilderness Park south to Plateau Mountain. It has not been previously reported for Willmore Wilderness Park. It is a plant of gravelly alpine slopes (Moss 1983) and is distributed from Alaska to Ellesmere Island, south to BC, Alberta, NWT, Hudson Bay and Quebec (Moss 1983).

\section{Viola pallens (Banks ex DC.) Brainerd (small white violet)}

\section{G5T5/S1}

Viola pallens is known as $V$. mackloskeyi in the Flora of Alberta (Moss 1983). However, true $V$. mackloskeyi is known only from California and Oregon (Douglas et al. 1991 p. 110) and our material is referable to $V$. pallens (J. Packer pers. comm.). Viola pallens grows in wet places from BC, Northwest Territories, east to Newfoundland and south to South Carolina, Michigan, Minnesota, Colorado and Washington (Douglas et al. 1991). In Alberta, it is known from the Rocky Mountains, foothills and central parkland near Edmonton. The discovery of this species near Topaz Lake is the first record for Jasper National Park.

\section{SUMMARY}

Twenty-nine rare taxa were noted from the study area during the course of the fieldwork in 1999. An additional eighteen rare vascular plants and 6 rare mosses have been reported for the area (Table 1) but were not reconfirmed during this work. Many of these are from areas not accessed this year. Ten of the twenty-nine species found are new records for either Willmore Wilderness Park or Jasper National Park. 

Table 1: Rare vascular plants and mosses known from Willmore Wilderness Park and northern Jasper National Park but not seen in 1999

\begin{tabular}{|l|l|}
\hline \multicolumn{1}{|c|}{ Scientific Name } & \multicolumn{1}{|c|}{ Common Name } \\
\hline Amblyodon dealbatus (Hedw.) B. S. G. & moss \\
\hline Aquilegia formosa Fisch. & Sitka columbine \\
\hline Botrychium minganense Victorin & Mingan moonwort \\
\hline Bryobrittonia longipes (Britt.) Horton & moss \\
\hline Bryum algovicum Sendtn. ex C. Mull. & moss \\
\hline Cardamine umbellata Greene & cress \\
\hline Carex heleonastes Ehrh. & Hudson Bay sedge \\
\hline Carex petricosa Dewey & stone sedge \\
\hline Cryptogramma stelleri (S. G. Gmel.) Prantl & Steller's rock brake \\
\hline Draba longipes Raup & whitlow-grass \\
\hline Epilobium lactiflorum L. & willowherb \\
\hline Erigeron flagellaris A. Gray & creeping fleabane \\
\hline Eriophorum callitrix Cham. & beautiful cotton grass \\
\hline Homalothecium pinnatifidum (Sull. \& Lesq.) Lawt. & moss \\
\hline Loiseleuria procumbens (L.) Desv. & alpine azalea \\
\hline Osmorhiza purpurea (Coult. \& Rose) Suksd. & purple sweet cicely \\
\hline Pedicularis langsdorfii ssp. arctica (R. Br.) Pennell & arctic lousewort \\
\hline Ranunculus nivalis L. & snow buttercup \\
\hline Ranunculus occidentalis var. brevistylis Greene & western buttercup \\
\hline Ribes laxiflorum Pursh & mountain currant \\
\hline Salix commutata Bebb & changeable willow \\
\hline Sphagnum compactum DC. ex Lam. \& DC. & neat bog moss \\
\hline Sphagnum lindbergii Schimp. ex Lindb. & Lindberg's bog moss \\
\hline Vaccinium uliginosum L. & bog bilberry \\
\hline
\end{tabular}

Additional work in Willmore and northern Jasper will likely result in discovery of additional populations of the above noted species and also in either rediscovery of old records or new additions to the flora of the area. Priorities for subsequent surveys are areas of diverse lithologies and areas previously reported to have rare taxa. Many of the reports of rare plants for the area have little information on population size or threat and, in many cases, the exact location cannot be determined from the report or herbarium label.

\section{REFERENCES}

Achuff, P. L. 1997. Special Plant and Landscape Features of Waterton Lakes National Park, Alberta. Waterton Lakes National Park, Waterton, Alberta. 75 pp.

Aiken, S. G. and S. J. Darbyshire. 1990. Fescue Grasses of Canada. Agriculture Canada Publicaiton 1844/E. Ottawa, ON. 113 pp.

Alberta Natural Heritage Information Centre. 2000. Data files. Alberta Environment, Edmonton.

Bayer, R. J. and G. L. Stebbins. 1993. A synopsis with keys for the genus Antennaria (Asteraceae: Inuleae: Gnaphaliinae) of North America. Canadian Journal of Botany 71:15891604.

Bork, E. 1991. Willmore Wilderness Park Final Report Re: Classification and Management of the Native Ranges in Willmore Wilderness Park. Range Management Section, Forest Land Use Branch, Alberta Forest Service, Edmonton, AB. 
Bork, E. 1994. Ecological Range Classification of Willmore Wilderness Park. Alberta Environmental Protection, Edmonton, $A B$

Douglas, G. W., G. B. Straley and D. Meidinger. 1991. The Vascular Plants of British Columbia. Part 3-Dicotyledons (Primulaceae through Zygophyllaceae) and Pteridophytes. BC Ministry of Forests. Special Report Series 3. 177 pp.

Geological Survey of Canada. 1964. Geology-Mount Robson. Map 1499A, Scale 1:250 000.

Packer, J. G. 1983. Flora of Alberta: Sparganium angustifolium and Erigeron trifidus. Canadian Journal of Botany 61(1):359-366.

Rollins, R. C. 1993. The Cruciferae of Continental North America. Stanford University Press, Stanford, California. 976 pp.

Vitt, D. H. and René J. Belland. 1996. Attributes of rarity among Alberta mosses: patterns and prediction of species diversity. The Bryologist 100(1):1-12.

Wagner, W. H. Jr. and J. M. Beitel. 1993. Lycopodiaceae. IN: Flora of North America, Vol. 2, Pteridophytes and Gymnosperms. Flora of North America Editorial Committee, Oxford University Press, New York. pp. 18-37.

Wolf, S. J., J. G. Packer and K. E. Denford. 1979. The taxonomy of Minuartia rossii (Caryophyllaceae). Canadian Journal of Botany 57(16):1673-1686. 

APPENDIX 1: ANHIC PLANT ELEMENT OCCURRENCES (EO'S)

WILLMORE WILDERNESS PARK AND NORTHERN JASPER NATIONAL PARK

15 

APPENDIX 2: VASCULAR PLANTS OBSERVED DURING THE COURSE OF THIS STUDY 



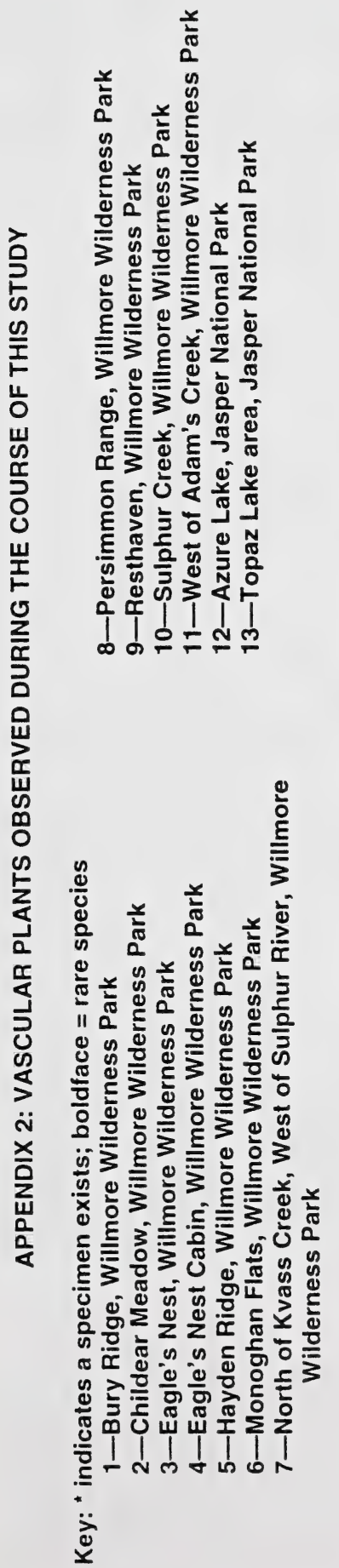

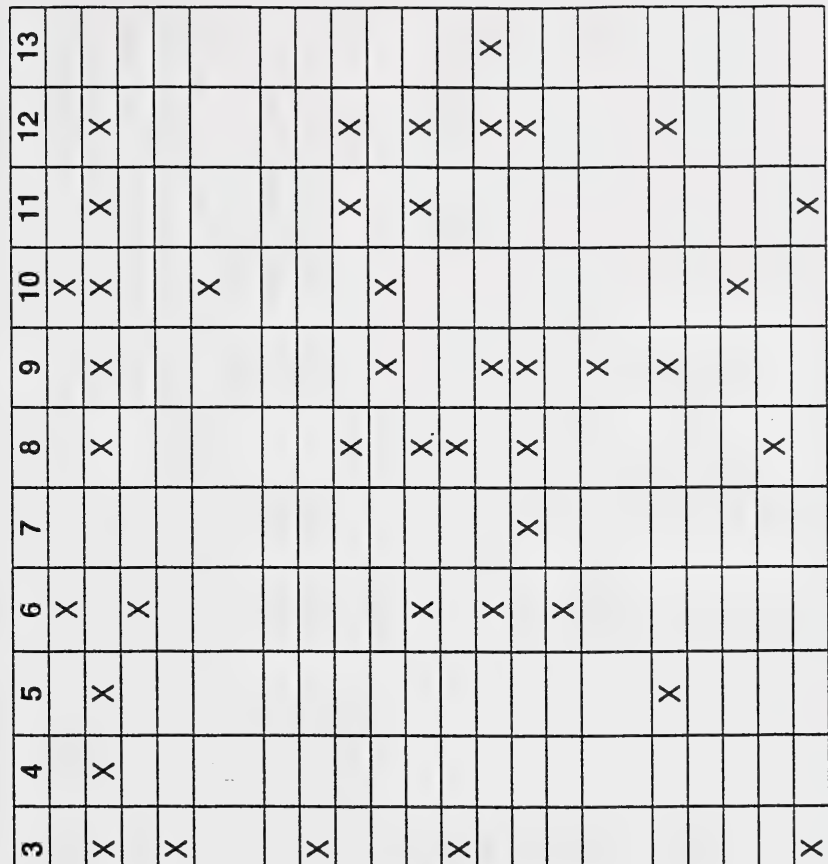

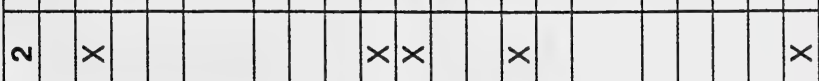

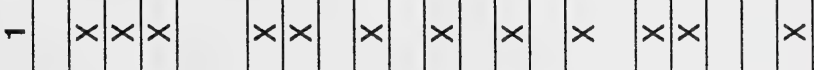

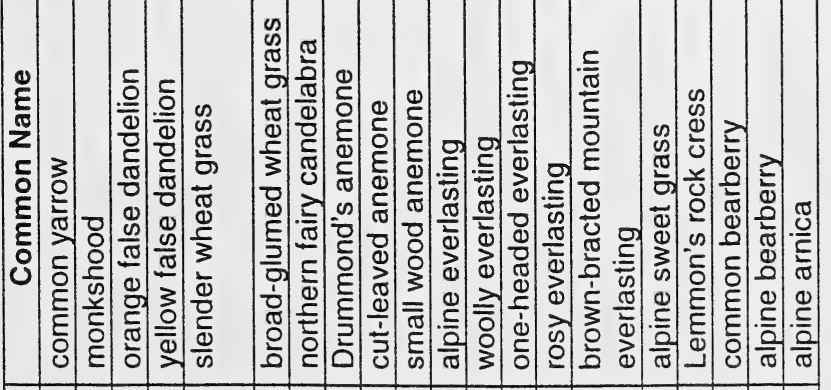

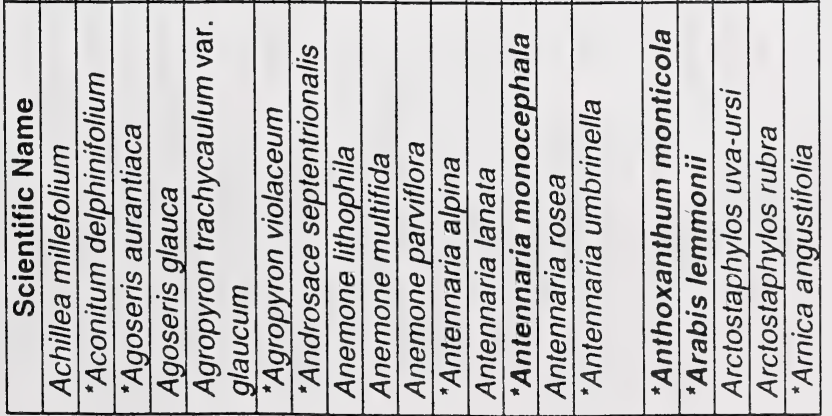





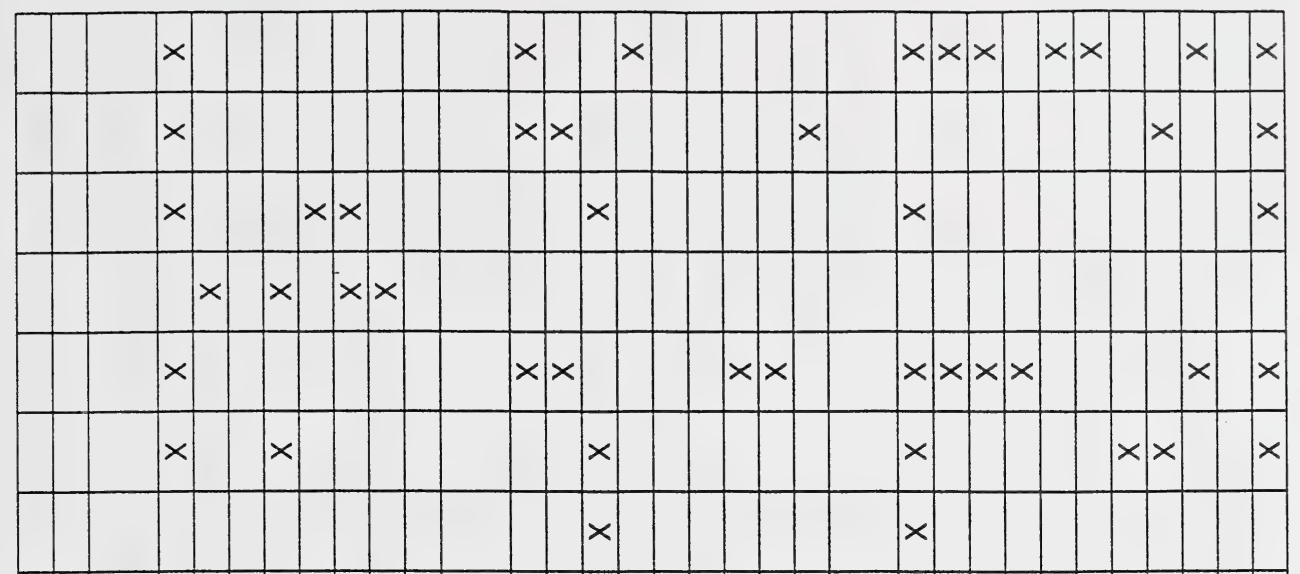

$\times x$

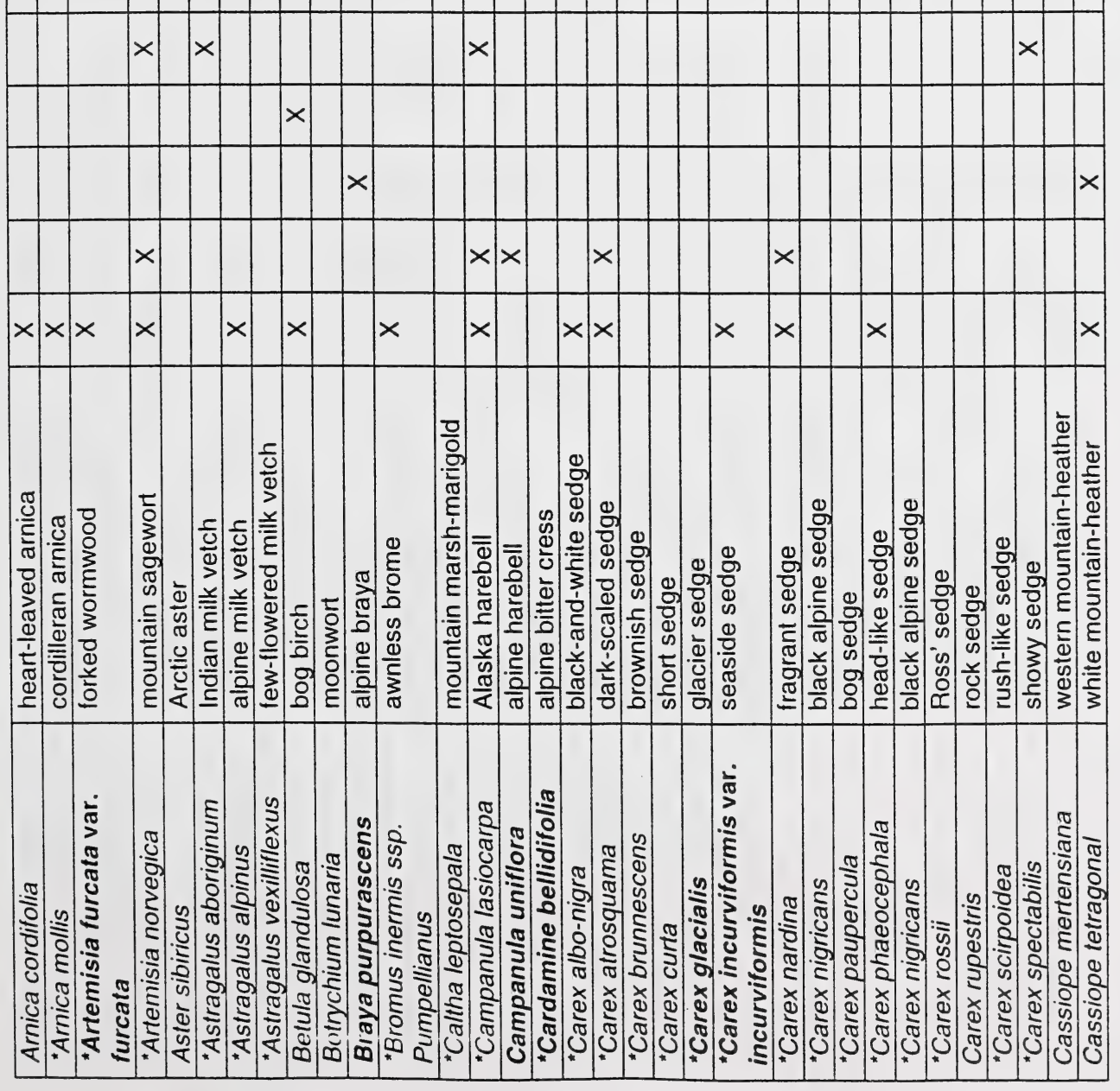





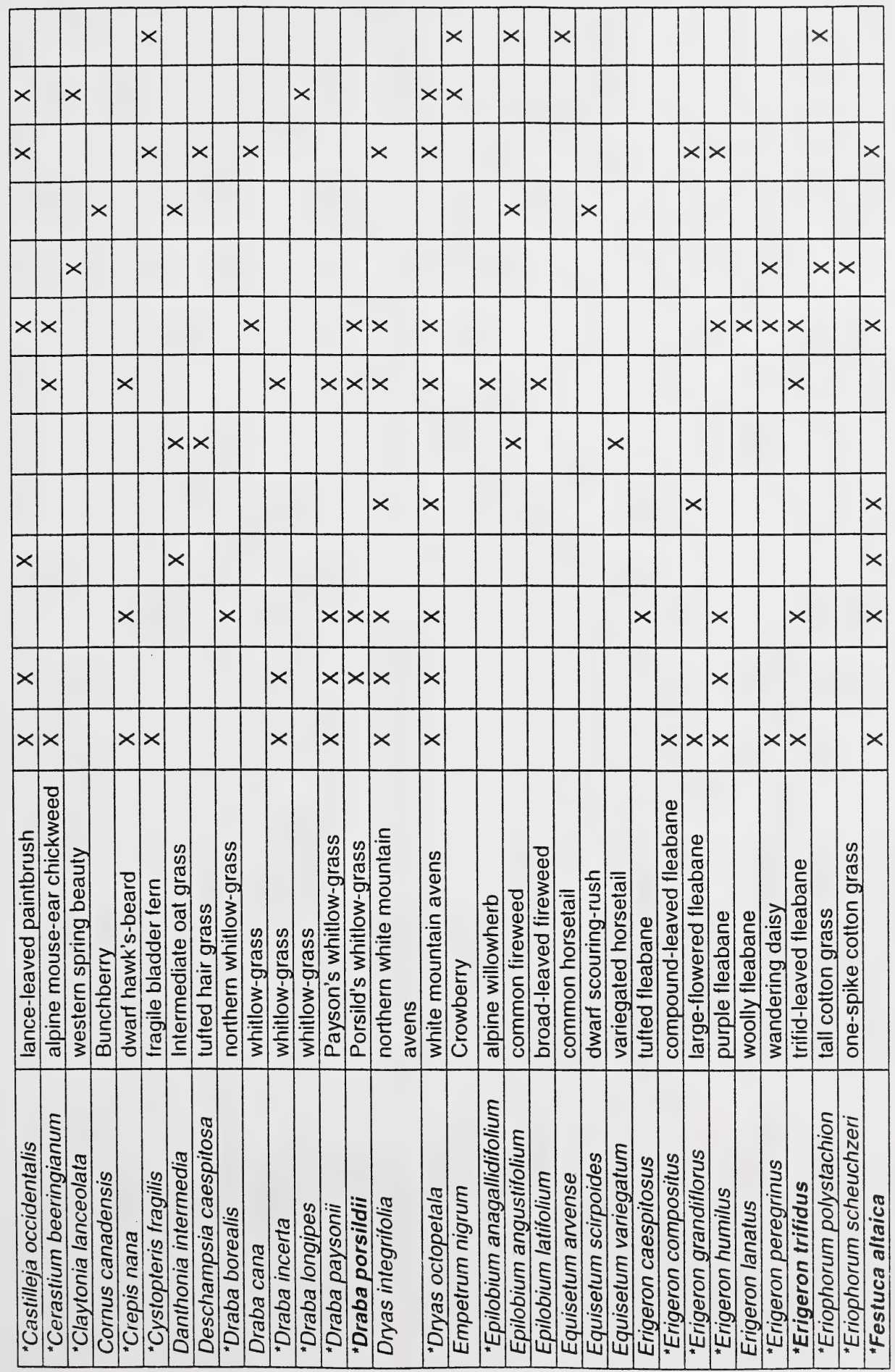





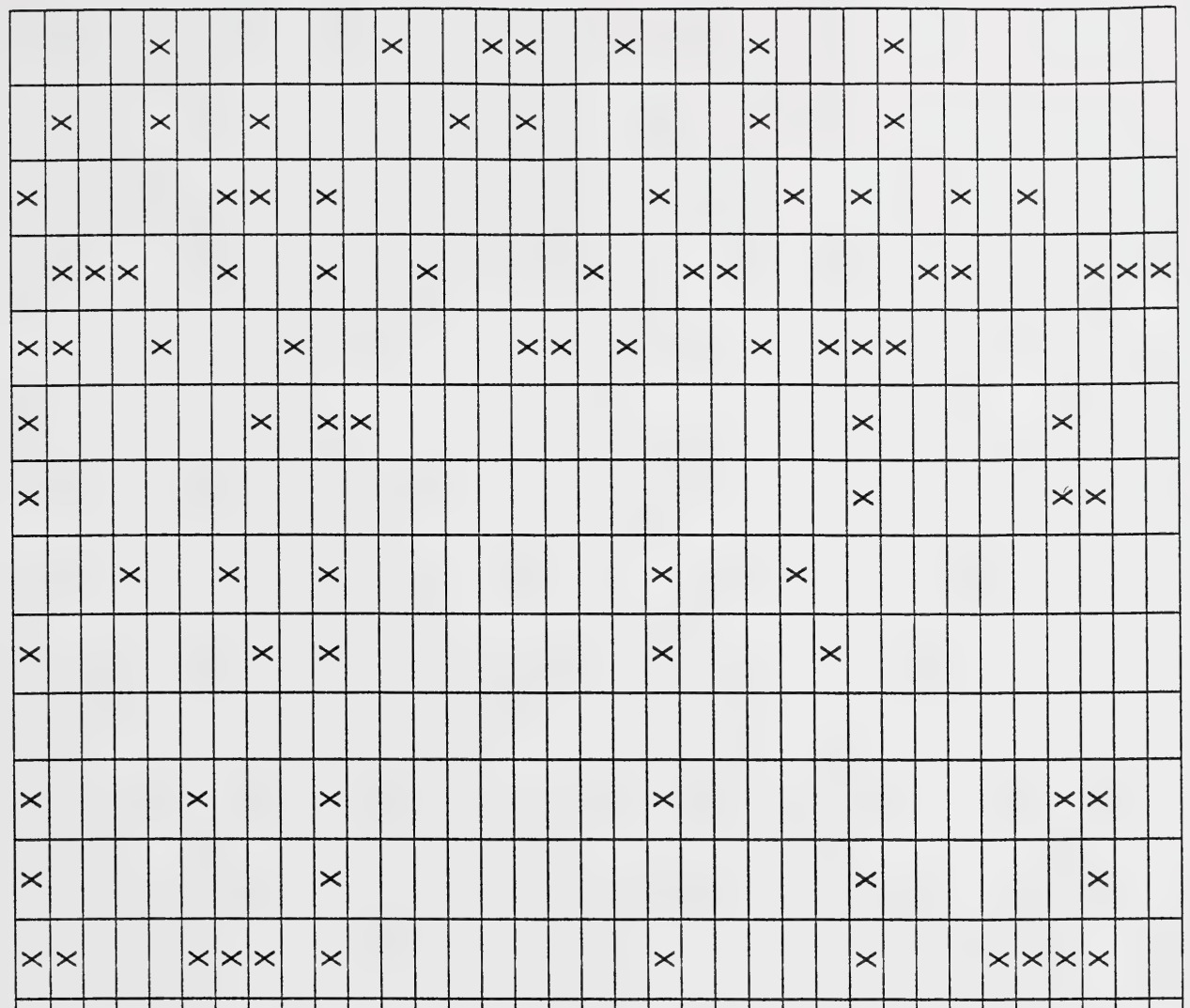

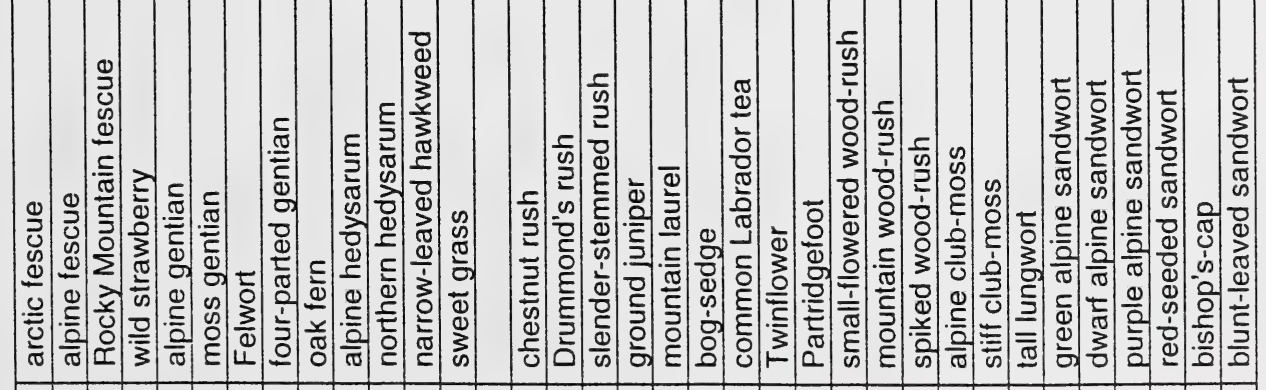

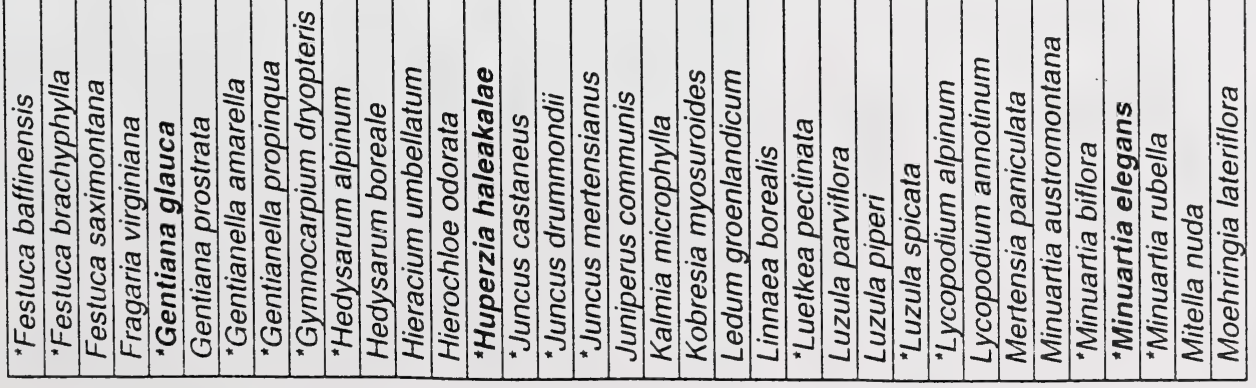





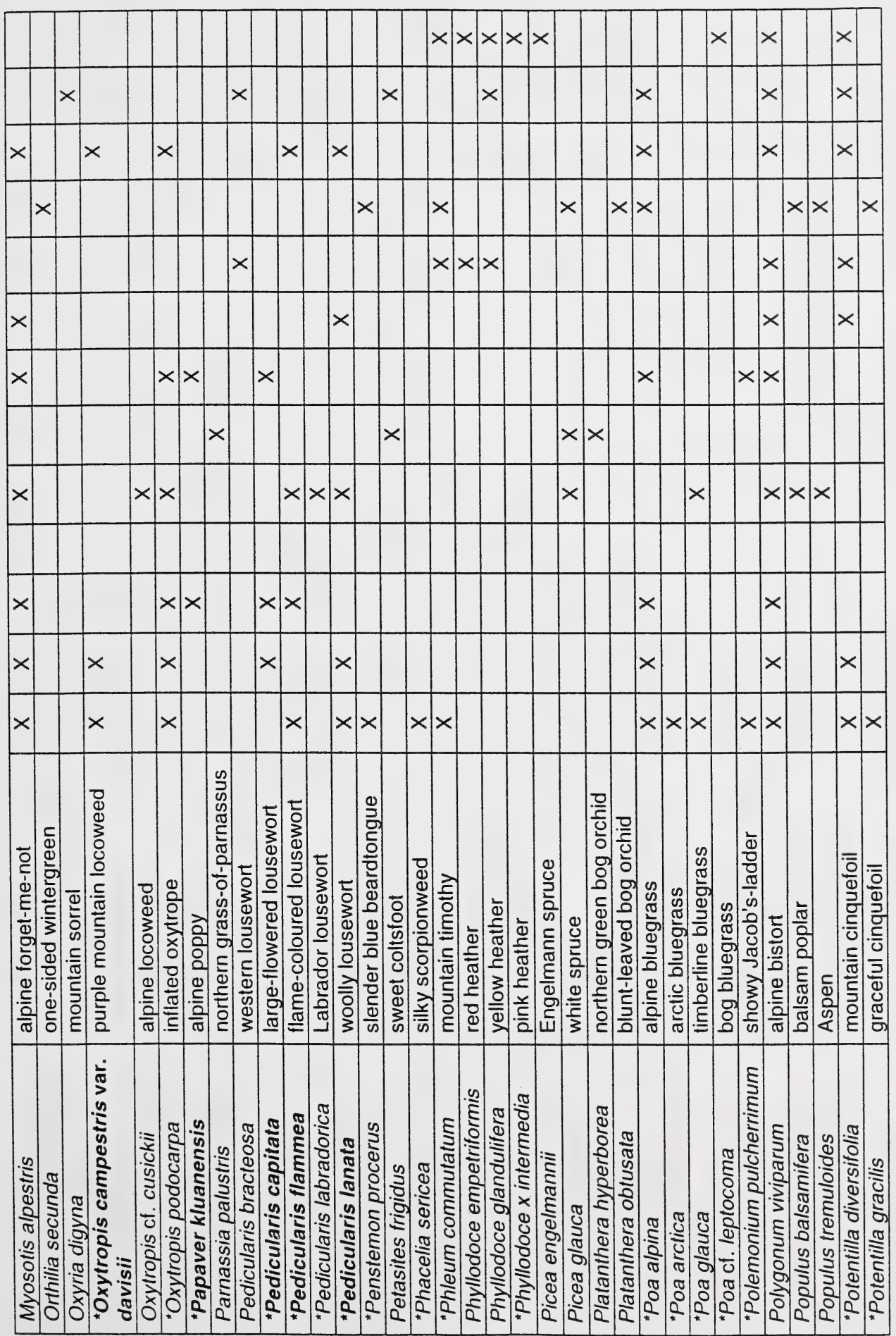





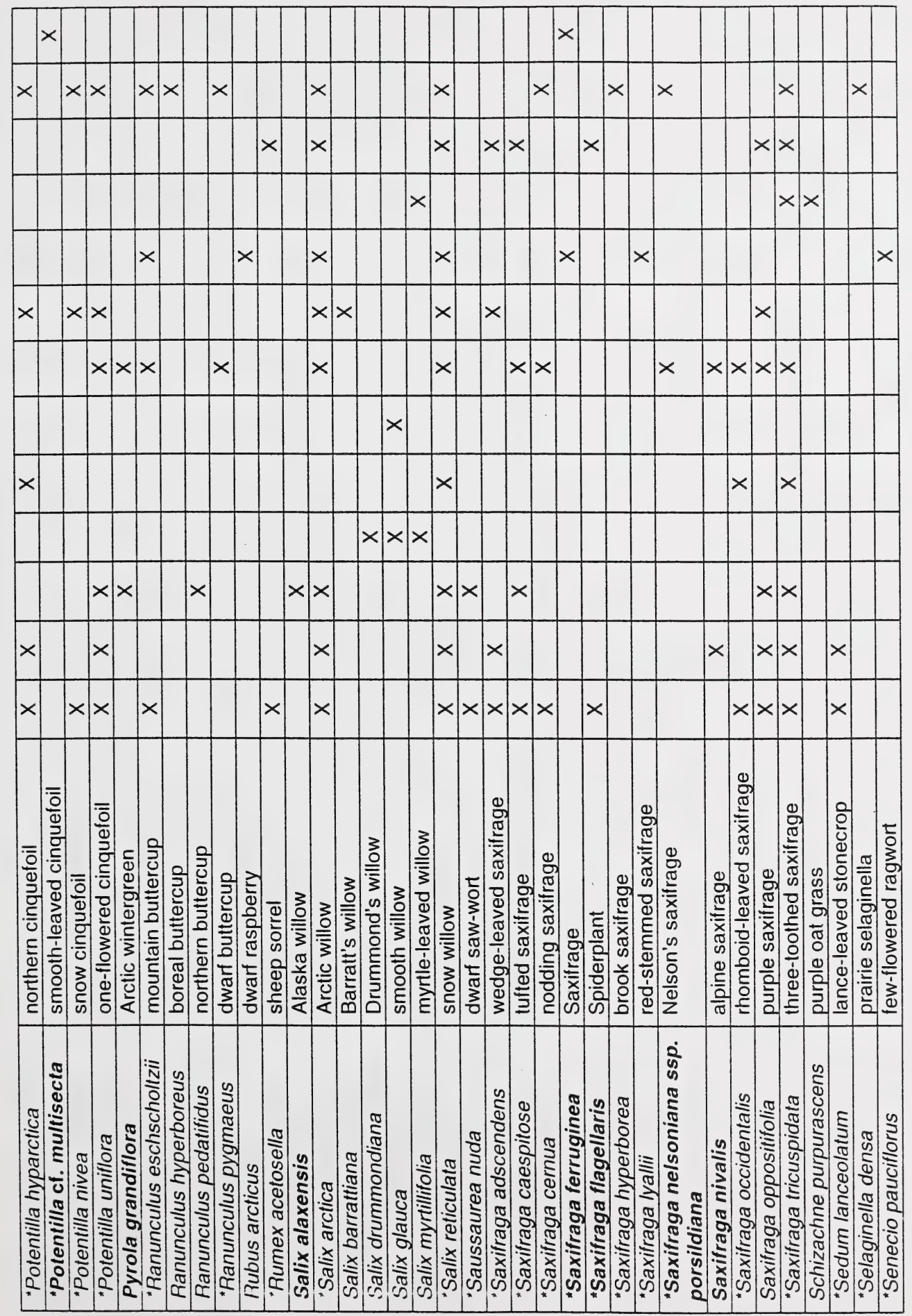





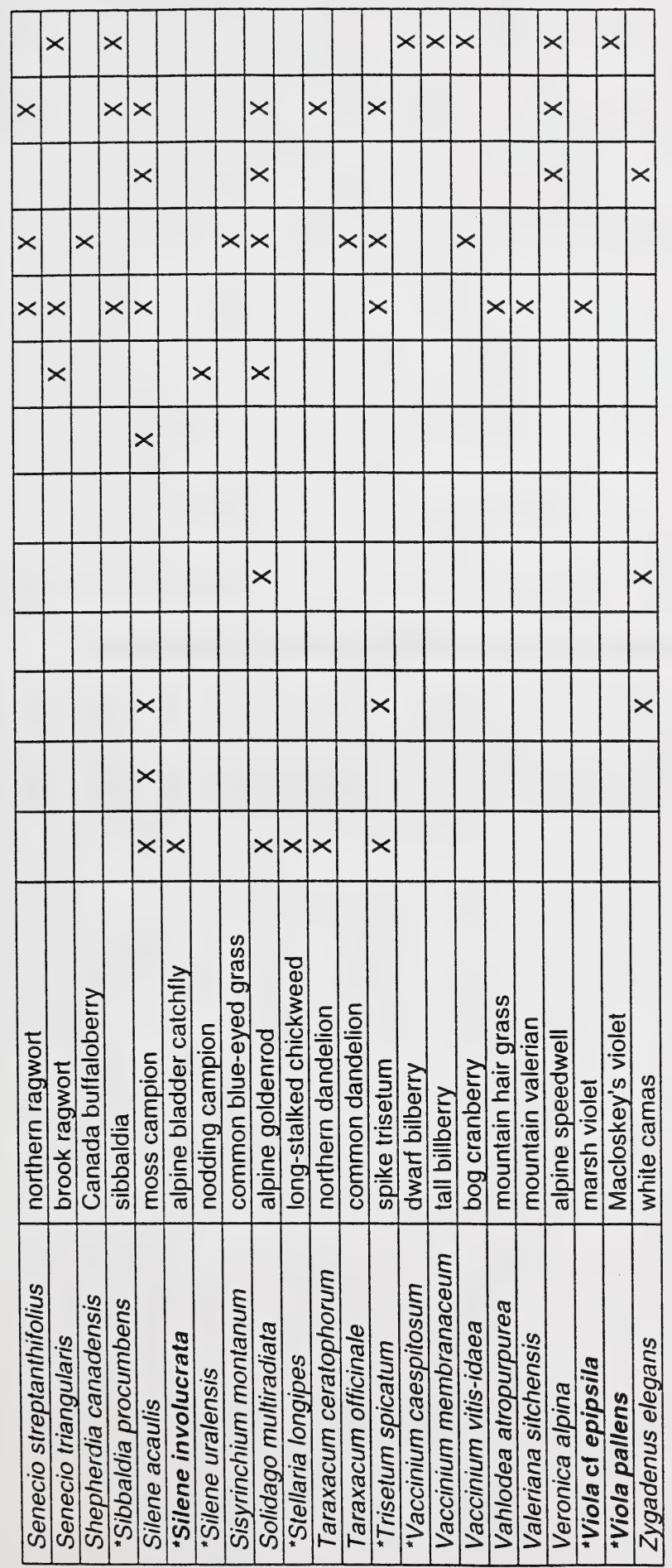





\section{APPENDIX 3: SAMPLE OF ELEMENT OCCURRENCE INFORMATION IN ANHIC}

The attached sample element occurrence information is for dot 5457 in Appendix 1. Detailed occurrence information for other dots indicated on the map can be obtained from John Rintoul, Alberta Natural Heritage Information Centre, Alberta Environment, $2^{\text {nd }}$ Floor, 9820106 Street, Edmonton, AB T5K 2J6, 780-427-6639. 

tennaria monocephala one-headed everlasting

Occurrence Code \#: 019

Actual Mapping Precision ( $m$ ):

Last Observed: 1999-08-05
SRank:

S2

Are Occurrences Tracked?:
Iment Code: PDASTOHOFO intification OK?: $Y$

ta Sensitive?: N vey Date: 1999-08-05 currence Type:
Data Entry Quality Checked? : N

\section{cation}

\begin{tabular}{|c|c|c|c|c|c|l|l|}
\hline Map & $\#$ & Dot ID \# & UTM Zone & UTM Easting & UTM Northing & Survey Site Name & Notes \\
\hline 83E11 & 4 & 5457 & 11 & 352361 & 5951128 & Childear Mt & $\begin{array}{l}\text { GPS: } 3523615951128 \text { \& 0352050 5951171 \& } \\
\text { (downslope) 351955 5951246 \& 352082 } \\
5951075\end{array}$ \\
\hline
\end{tabular}

fections: Willmore Wilderness Park; ca. $4.5 \mathrm{~km} \mathrm{NE}$ of Childear Mt; W-fac. slope of saddle

eneral Description: W-fac. slope of saddle; turfy area with Dryas oct-Sali niv/lichen-moss ct

In Elev. $(\mathrm{m}): 2164 \quad$ Slope: Size of Occurrence:

ax Elev. $(\mathrm{m}): 2195 \quad$ Aspect: $W$

\section{ccurrence Data}

\begin{tabular}{|c|l|l|l|}
\hline Date & Occurrence Data & Source Abstract Code & Observer \\
\hline 1999-08-05 & See field notes & F99GOU01ABCA & $\begin{array}{l}\text { J Gould, C Lane, M Willoughby, E } \\
\text { Marshall }\end{array}$ \\
\hline
\end{tabular}

\section{anagement Comments:}

her Comments: 18 plants counted; also pres. downslope in Drya octlichen tundra

\section{NFORMATION SOURCES}

est Source of Info: S99GOUPPABCA28

\section{Decimens}

\begin{tabular}{|c|l|l|l|c|c|c|}
\hline Date & Observation Detail & Collector & Herbarium & Accession \# & ID OK? & Specimen Source Code \\
\hline $1999-08-05$ & & J Gould & PP & 3669 & Y & S99GOUPPABCA28 \\
\hline
\end{tabular}

\section{ocuments}

\begin{tabular}{|l|l|c|l|l|}
\hline Source Code & Author & Year & Title & Publisher \\
\hline F99GOU01ABCA & Gould, Joyce & 1999 & Field Notes (the site is described) & \\
\hline
\end{tabular}



aba porsildi Porsild's whitlow-grass

SRank:

ment Code: PDBRA11200 entification OK?:

ta Sensitive?: $N$

iney Date: 1999-08-05

Occurrence Code \#:003

Actual Mapping Precision (m):

Last Observed: 1999-08-05
Data Entry Quality Checked? : N

50 Precision Code: S

:currence Type:

\section{cation}

\begin{tabular}{|c|c|c|c|c|c|l|l|}
\hline Map & $\#$ & Dot ID $\#$ & UTM Zone & UTM Easting & UTM Northing & Survey Site Name & Notes \\
\hline 83E11 & 4 & 5457 & 11 & 352361 & 5951128 & Childear Mt & $\begin{array}{l}\text { GPS: } 3523615951128 \& 03520505951171 \& \\
\text { (downslope) 351955 5951246 \& 352082 } \\
5951075\end{array}$ \\
\hline
\end{tabular}

rections: Willmore Wildemess Park; ca. $4.5 \mathrm{~km} \mathrm{NE}$ of Childear Mt

eneral Description: Salix arctica/Sali nivalis/Dryas tundra (Site 5-2)

in Elev. (m): 1905 Slope: Size of Occurrence:

ax Elev. $(m): 1981 \quad$ Aspect: $W$

ccurrence Data

\begin{tabular}{|c|l|l|l|}
\hline Date & Occurrence Data & Source Abstract Code & Observer \\
\hline 1999-08-05 & GPS read.: 3520825951075 & F99GOU01ABCA & $\begin{array}{l}\text { J Gould, C Lane, M Willoughby, E } \\
\text { Marshall }\end{array}$ \\
\hline
\end{tabular}

anagement Comments:

ther Comments: specimen entry needed

\section{NFORMATION SOURCES}

est Source of info: F99GOU01ABCA

pecimens

\section{ocuments}

\begin{tabular}{|l|l|l|l|l|}
\hline Source Code & Author & Year & Title & Publisher \\
\hline F99GOU01ABCA & Gould, Joyce & 1999 & Field Notes (the site is described) & \\
\hline
\end{tabular}



ment Code: PDCAM020YO intification OK?: $Y$ Actual Mapping Precision (m):

Occurrence Code \#: 017

la Sensitive?: $N$

vey Date: 1999-08-05

Last Observed: 1999-08-05
Data Entry Quality Checked?： N

50

currence Type:

\section{cation}

\begin{tabular}{|c|c|c|c|c|c|l|l|}
\hline Map & $\#$ & Dot ID \# & UTM Zone & UTM Easting & UTM Northing & Survey Site Name & Notes \\
\hline $83 E 11$ & 4 & 5457 & 11 & 352361 & 5951128 & Childear Mt & $\begin{array}{l}\text { GPS: } 3523615951128 \& 03520505951171 \& \\
\text { (downslope) 351955 5951246 \& 352082 } \\
5951075\end{array}$ \\
\hline
\end{tabular}

ections: Willmore Wilderness Park; ca. $4.5 \mathrm{~km} \mathrm{NE}$ of Childear Mt; W slope of saddle

neral Description: $\quad$ W slope of saddle, downslope; Salix archichen-moss tundra

Elev. $(\mathrm{m}): 2164$ Slope: Size of Occurrence:

ix Elev. $(\mathrm{m}): 2195 \quad$ Aspect: $W$

\section{scurrence Data}

\begin{tabular}{|c|l|l|l|}
\hline Date & Occurrence Data & Source Abstract Code & Observer \\
\hline $1999-08-05$ & See field notes & F99GOu01ABCA & $\begin{array}{l}\text { J Gould, C Lane, M Willoughby, E } \\
\text { Marshall }\end{array}$ \\
\hline
\end{tabular}

\section{anagement Comments:}

her Comments: In flower

\section{IFORMATION SOURCES}

st Source of Info: F99GOU01ABCA

becimens

\section{bcuments}

\begin{tabular}{|l|l|c|l|l|}
\hline Source Code & Author & Year & Tite & Publisher \\
\hline 99GOU01ABCA & Gould, Joyce & 1999 & Field Notes (the site is described) & \\
\hline
\end{tabular}



nent Code: POFAB2X04A

atification $O K$ ?: $Y$

a Sensitive?: N

vey Date: $1999-08-04$

furrence Type:
Occurrence Code \#:019

Actual Mapping Precision (m):

Last Observed: 1999-08-04
Data Entry Quality Checked?: N

50 Precision Code: S

\begin{tabular}{|c|c|c|c|c|c|c|c|}
\hline Map & $\#$ & Dot ID\# & UTM Zone & UTM Easting & UTM Northing & Survey Site Name & Notes \\
\hline $83 E 11$ & 4 & 5457 & 11 & 352361 & 5951128 & Childear Mt & $\begin{array}{l}\text { GPS: } 3523615951128 \& 03520505951171 \& \\
\text { (downslope) } 3519555951246 \& 352082 \\
5951075\end{array}$ \\
\hline
\end{tabular}

ections: Willmore Wilderness Park; Childear Mt-Kvass Creek area; ridge ca. $4.5 \mathrm{~km} \mathrm{NE}$ of Childear Mt

heral Description: Dryas integrifolialichen tundra, slope of saddle

$\begin{array}{llll}\text { Elev. }(m): & 2164 & \text { Slope: } & \text { Size of Occurrence: } \\ x \text { Elev. }(m): & 2195 & \text { Aspect: W }\end{array}$

currence Data

\begin{tabular}{|c|l|l|l|}
\hline Date & Occurrence Data & Source Abstract Code & Observer \\
\hline $1999-08-04$ & See field notes & F99GoU01ABCA & $\begin{array}{l}\text { J Gould, C Lane, M Willoughby, E } \\
\text { Marshall }\end{array}$ \\
\hline
\end{tabular}

inagement Comments:

her Comments:

\section{IFORMATION SOURCES}

st Source of Info: S99GOUPPABCA29

becimens

\begin{tabular}{|c|l|l|l|c|c|c|}
\hline Date & Observation Detail & Collector & Herbarium & Accession \# & 10 OK? & Specimen Source Code \\
\hline $1999-08-05$ & & J Gould & PP & 3674 & Y & S99GOUPPABCA29 \\
\hline
\end{tabular}

\section{ocuments}

\begin{tabular}{|l|l|c|l|l|}
\hline Source Code & Author & Year & Title & Publisher \\
\hline 99GOU01ABCA & Gould, Joyce & 1999 & Field Notes (the site is described) & \\
\hline
\end{tabular}



ment Code: PDSAXOU140 intification OK?: $Y$ Actual Mapping Precision (m):

Occurrence Code \#: 016

ta Sensitive?: $N$

ivey Date: 1999-08-05

Last Observed: 1999-08-05
Data Entry Quality Checked? : N

50 Precision Code: S

currence Type:

\section{cation}

\begin{tabular}{|c|c|c|c|c|c|l|l|}
\hline Map & $\#$ & Dot ID \# & UTM Zone & UTM Easting & UTM Northing & Survey Site Name & Notes \\
\hline 83E11 & 4 & 5457 & 11 & 352361 & 5951128 & Childear Mt & $\begin{array}{l}\text { GPS: } 3523615951128 \text { \& 0352050 5951171 \& } \\
\text { (downslope) 351955 5951246 \& 352082 } \\
5951075\end{array}$ \\
\hline
\end{tabular}

rections: Willmore Wildemess Park; ca. $4.5 \mathrm{~km}$ NE of Childear Mt; W-fac. slope of saddle

meral Description: $\quad$ W-fac., downslope from top: Salix arc-Salix niv tundra

Elev. $(\mathrm{m}): 2164 \quad$ Slope: Size of Occurrence:

ax Elov. $(\mathrm{m}): 2195 \quad$ Aspect: $W$

\section{ccurrence Data}

\begin{tabular}{|c|l|l|l|}
\hline Date & Occurrence Data & Source Abstract Code & Observer \\
\hline 1999-08-05 & See field notes & F99Gou01ABCA & $\begin{array}{l}\text { J Gould, C Lane, M Willoughby, E } \\
\text { Marshall }\end{array}$ \\
\hline
\end{tabular}

\section{anagement Comments:}

her Comments: Good 10

\section{VFORMATION SOURCES}

est Source of Info: S99GOUPPABCA30 pecimens

\begin{tabular}{|c|l|l|l|c|c|c|}
\hline Date & Observation Detail & Collector & Herbarium & Accession \# & 1D OK? & Specimen Source Code \\
\hline $1999-08-05$ & & J Gould & PP & 3676 & Y & S99GOUPPABCA30 \\
\hline
\end{tabular}

\section{ocuments}

\begin{tabular}{|l|l|l|l|l|}
\hline Source Code & Author & Year & Title & Publisher \\
\hline F99GOU01ABCA & Gould, Joyce & 1999 & Field Notes (the site is described) & \\
\hline
\end{tabular}




$$
\text { . }
$$


dicularis capitata large-flowered lousewort

SRank:

S2

Are Occurrences Tracked?: $Y$

nent Code: PDSCR1K060

itification OK?: $Y$

a Sensitive?: $N$

vey Date: 1999-08-04

zurrence Type:
Occurrence Code \#: 025

Actual Mapping Precision (m):

Last Observed: 1999-08-04
Data Entry Quality Checked? : N

50

Precision Code: S

\section{cation}

\begin{tabular}{|l|c|c|c|c|c|l|l|}
\hline Map & $\#$ & Dot ID $\#$ & UTM Zone & UTM Easting & UTM Northing & Survey Site Name & Notes \\
\hline 83E11 & 4 & 5457 & 11 & 352361 & 5951128 & Childear Mt & $\begin{array}{l}\text { GPS: } 3523615951128 \& 03520505951171 \& \\
\text { (downslope) 351955 5951246 \& 352082 } \\
5951075\end{array}$ \\
\hline
\end{tabular}

ections: Willmore Wildemess Park; Childear Mt-Kvass Creek area; ridge ca. $4.5 \mathrm{~km}$ NE of Childear Mt

heral Description: Dryas integrifolia Michen tundra; Dryas int-Sali arc tundra with striping. W-fac. slope of saddle

Elev. $(\mathrm{m}): 2164 \quad$ Slope: Size of Occurrence:

x Elev. $(m): 2195 \quad$ Aspect:

ccurrence Data

\begin{tabular}{|c|l|l|l|}
\hline Date & Occurrence Data & Source Abstract Code & Observer \\
\hline $1999-08-04$ & See field notes & F99Gou01ABCA & $\begin{array}{l}\text { J Gould, C Lane, M Willoughby, E } \\
\text { Marshall }\end{array}$ \\
\hline
\end{tabular}

anagement Comments:

her Comments: 100's of plants on W-fac. slope of saddle; also on lower slopes in Salix arc-Dryas oct/mossfichen ct

\section{IFORMATION SOURCES}

st Source of Info: F99GOU01ABCA

becimens

\section{ocuments}

\begin{tabular}{|l|l|c|l|l|}
\hline Source Code & Author & Year & Title & Publisher \\
\hline 99GOU01ABCA & Gould, Joyce & 1999 & Field Notes (the site is described) & \\
\hline
\end{tabular}



ment Code: POSCR1KOLO intification OK?: $Y$ Actual Mapping Precision (m):

Occurrence Code \#: 024

ta Sensitive?: N

vey Date: 1999-08-04

Last Observed: 1999-08-04
Data Entry Quality Checked?: N

50 Precision Code: S

\section{currence Type:}

\section{cation}

\begin{tabular}{|c|c|c|c|c|c|l|l|}
\hline Map & $\#$ & Dot ID \# & UTM Zone & UTM Easting & UTM Northing & Survey Site Name & Notes \\
\hline 83E11 & 4 & 5457 & 11 & 352361 & 5951128 & Childear Mt & $\begin{array}{l}\text { GPS: } 3523615951128 \text { \& 0352050 5951171 \& } \\
\text { (downslope) 351955 5951246 \& 352082 } \\
5951075\end{array}$ \\
\hline
\end{tabular}

ections: Willmore Wildemess Park; Childear Mt-Kvass Creek area; ridge ca. $4.5 \mathrm{~km}$ NE of Childear Mt

neral Description: Dryas integrifolialichen tundra \& Drya int-Sali arct tundra with striping on W-fac. slope of saddle

Elev. $(\mathrm{m}): 2164 \quad$ Slope: Size of Occurrence:

ax Elev. $(m): 2195 \quad$ Aspect: $W$

\section{ccurrence Data}

\begin{tabular}{|c|l|l|l|}
\hline Date & Occurrence Data & Source Abstract Code & Observer \\
\hline 1999-08-04 & See field notes & F99GOU01ABCA & $\begin{array}{l}\text { J Gould, C Lane, M Willoughby, E } \\
\text { Marshall }\end{array}$ \\
\hline
\end{tabular}

\section{anagement Comments:}

her Comments: Also present downslope in Salix arc/moss ct but not as abundant as upper slopes

\section{UFORMATION SOURCES}

est Source of Info: F99GOU01ABCA

\section{becimens}

\section{ocuments}

\begin{tabular}{|l|l|l|l|l|}
\hline Source Code & Author & Year & Title & Publisher \\
\hline 99GOU01ABCA & Gould, Joyce & 1999 & Field Notes (the site is described) & \\
\hline
\end{tabular}





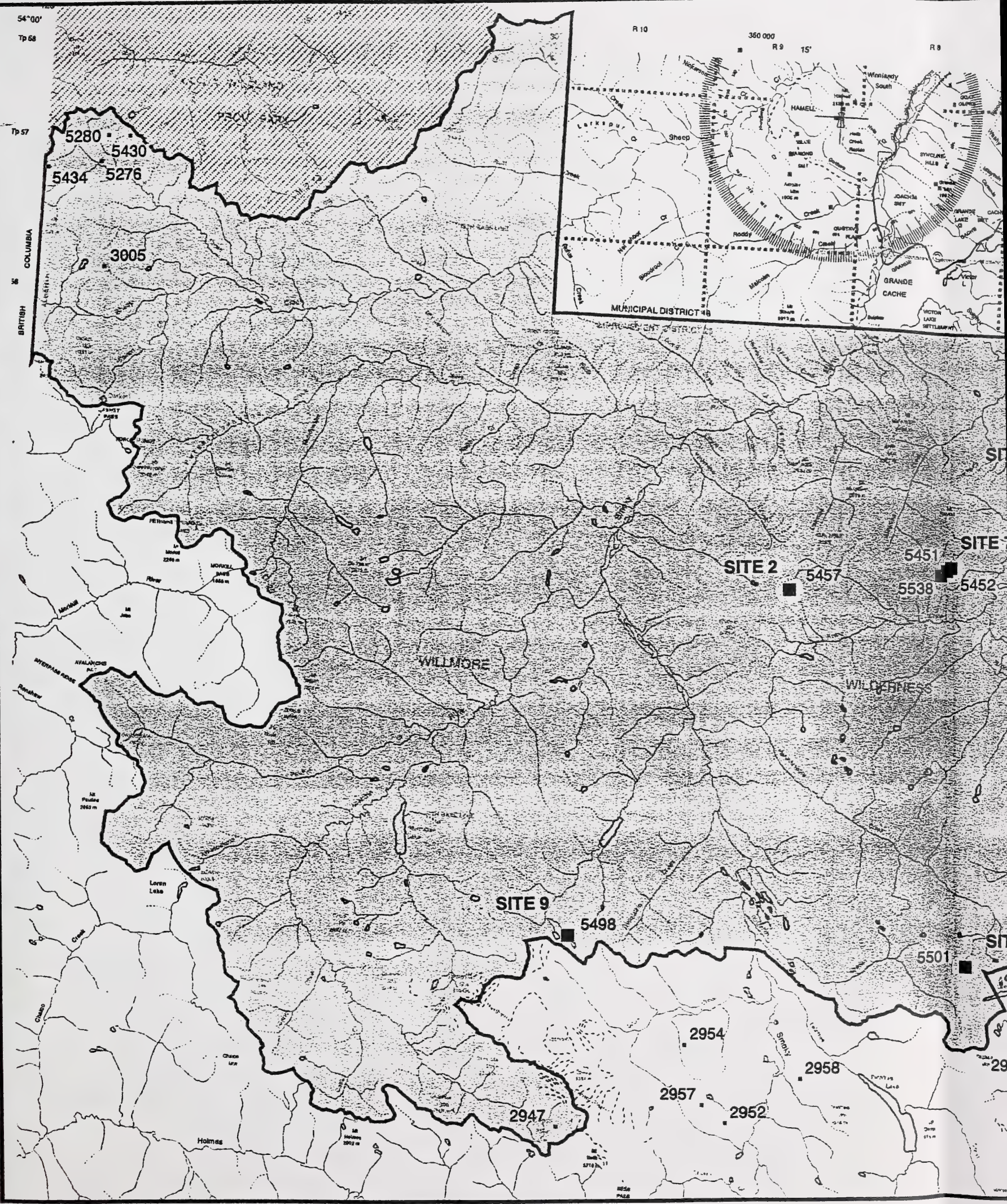




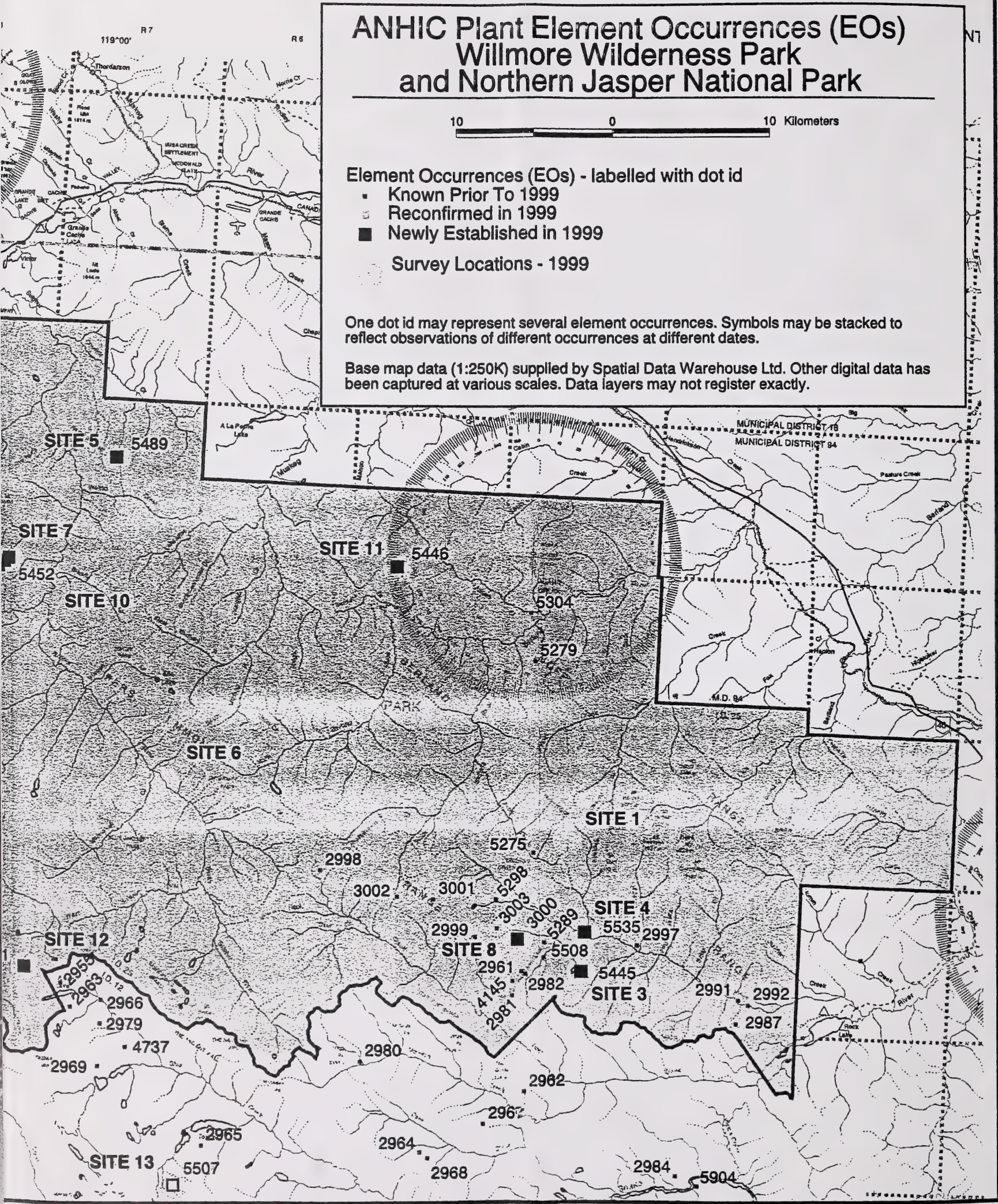


APPENDIX E:

WILLMORE WILDERNESS PARK

NOXIOUS WEED INFESTATIONS 

APPENDIX E:

WILLMORE WILDERNESS PARK

NOXIOUS WEED INFESTATIONS 



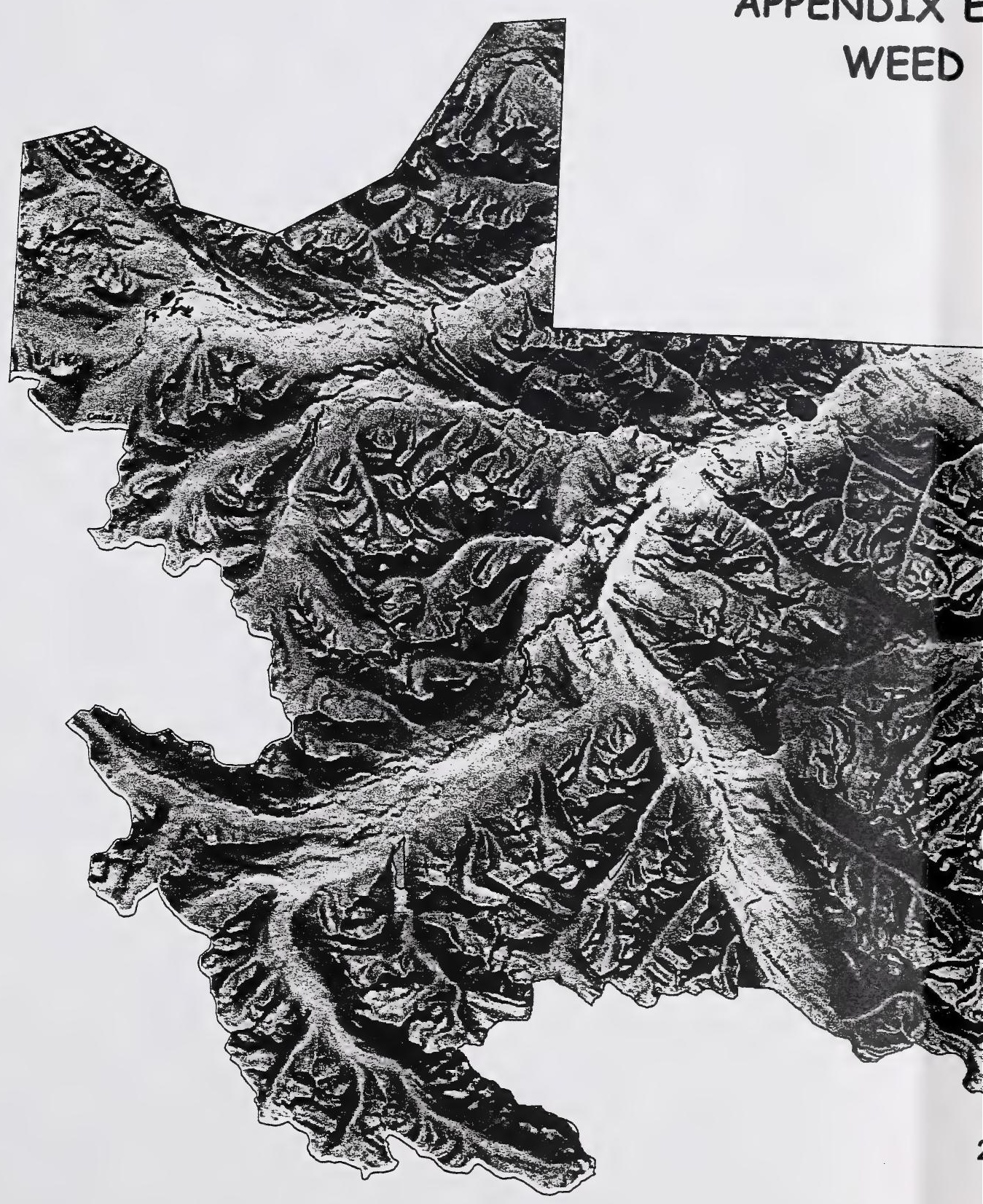

h:larcview proj 


\title{
E: WILLMORE WILDERNESS PARK INFESTATION INVENTORY
}

\author{
Text Big Hydro Text \\ Willmore.shp \\ - T. Buttercup \\ Willmore Range Inv.
}
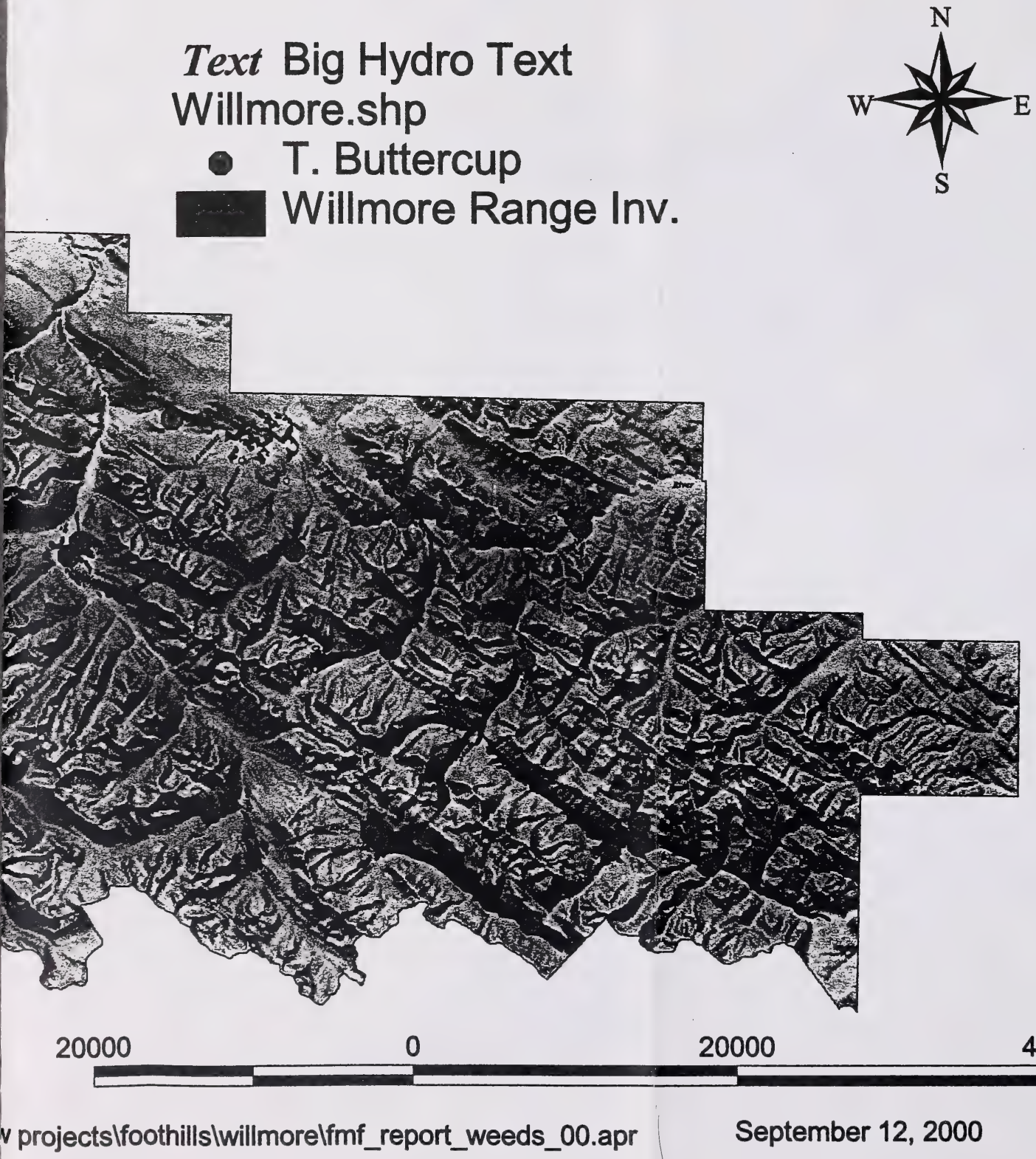

September 12, 2000 




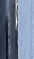

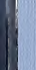


National Library of Canada
Bibliotheque nationale du Canada

|||||||||||||||||||||||||

33286520962313 